San Jose State University

SJSU ScholarWorks

Master's Theses

Master's Theses and Graduate Research

1994

\title{
The value of traditional and technology-mediated library services to students enrolled in two universities that offer off-site degree programs / c by Michelle R. Stiles
}

Michelle R. Stiles

San Jose State University

Follow this and additional works at: https://scholarworks.sjsu.edu/etd_theses

\section{Recommended Citation}

Stiles, Michelle R., "The value of traditional and technology-mediated library services to students enrolled in two universities that offer off-site degree programs / c by Michelle R. Stiles" (1994). Master's Theses. 956.

DOI: https://doi.org/10.31979/etd.cy4f-p8br

https://scholarworks.sjsu.edu/etd_theses/956

This Thesis is brought to you for free and open access by the Master's Theses and Graduate Research at SJSU ScholarWorks. It has been accepted for inclusion in Master's Theses by an authorized administrator of SJSU ScholarWorks. For more information, please contact scholarworks@sjsu.edu. 


\title{
THE VALUE OF TRADITIONAL AND TECHNOLOGY-MEDIATED IIBRARY SERVICES TO STUDENTS ENROLLED IN TWO UNIVERSITIES THAT OFFER OFF-SITE DEGREE PROGRAMS
}

\author{
A Thesis \\ Presented to \\ The faculty of the school of \\ Iibrary and Information Science \\ San Jose State university
}

In Partial Fulfillment

of the Requirements for the Degree

Master of Library Science

by

Michelle R. Stiles

December, 1994 
DMI Number: 1361215

UMT Microform Edition 1361215

Copyright 1995, by UMI Company. All rights reserved.

This microform edition is protected against unauthorized copying under ritle 17, United States code.

\section{UMI}

300 North Zeeb Road

Ann Arbor, MI 48103 
- 1994

Michelie R. Stiles

ALI RIGHTS RESERVED 
APPROVED FOR THE SCHOOL OF IIERARY

AND INFORMATION SCIENCE

Wiblea lat

Dr. William Fisher

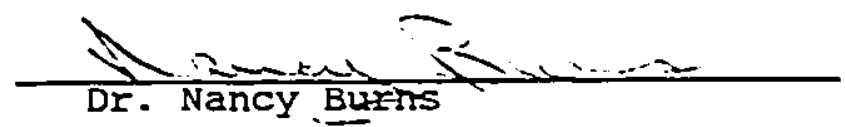

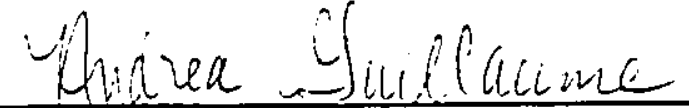

Dr. Andrea Guillaume

APPROVED FOR THE UNIVERSITY

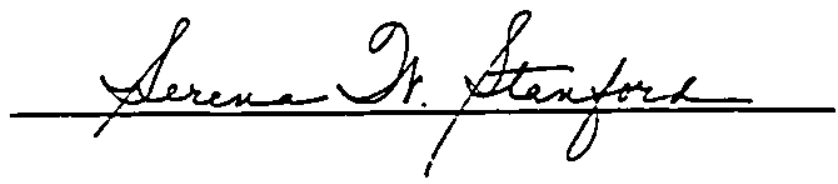




\section{ABSTRACT}

THE VALUE OF TRADITIONAL AND TECHNOLOGY-MEDIATED LIBRARY SERVICES TO STUDENTS ENROLIED IN TWO UNIVERSITIES THAT OFFER OFF-SITE

DEGREE PROGRAMS

by Michelle R. Stiles

This thesis examines students' and faculty's perception, value and use of technology-mediated, electronic library services and traditional library services in two university settings that offer technology-mediated services to support their off-site, non-traditional degree programs. It studies this population to determine if technologymediated, electronic library services have replaced the traditional library in these academic settings.

This research reveals that many students and faculty do not use or are unaware of the offered services. A large number of study respondents indicated they had used other library services, usually public libraries, six times or more in the past six months. Participants indicated they place a high value on electronic and traditional library services individually; however, both services combined are very valuable. These results indicate that technologymediated, electronic services have not replaced the traditional library in these academic settings. 
List of Tables . . . . . . . . . . . . . . . . viii

CHAPTER 1 Introduction . . . . . . . . . . . . . 1

CHAPTER 2 Literature Review . . . . . . . . . . 8

Technology Use . . . . . . . . . . . . . . 9

Distance/Off-Campus Education . . . . . . . . 17

CHAPTER 3 The sites . . . . . . . . . . . . . 25

University Background . . . . . . . . . . . 25

Library Services . . . . . . . . . . . . . 29

CHAPTER 4 Method . . . . . . . . . . . . . 32

Study Participants . . . . . . . . . . . . 33

Procedure . . . . . . . . . . . . . . 33

Sample selection . . . . . . . . . 33

Survey Design and Testing . . . . . . . 34

Survey Distribution/Administration . . . . 35

Quantitative Data Analysis . . . . . . 36

Qualitative Data Analysis . . . . . . . . 37 


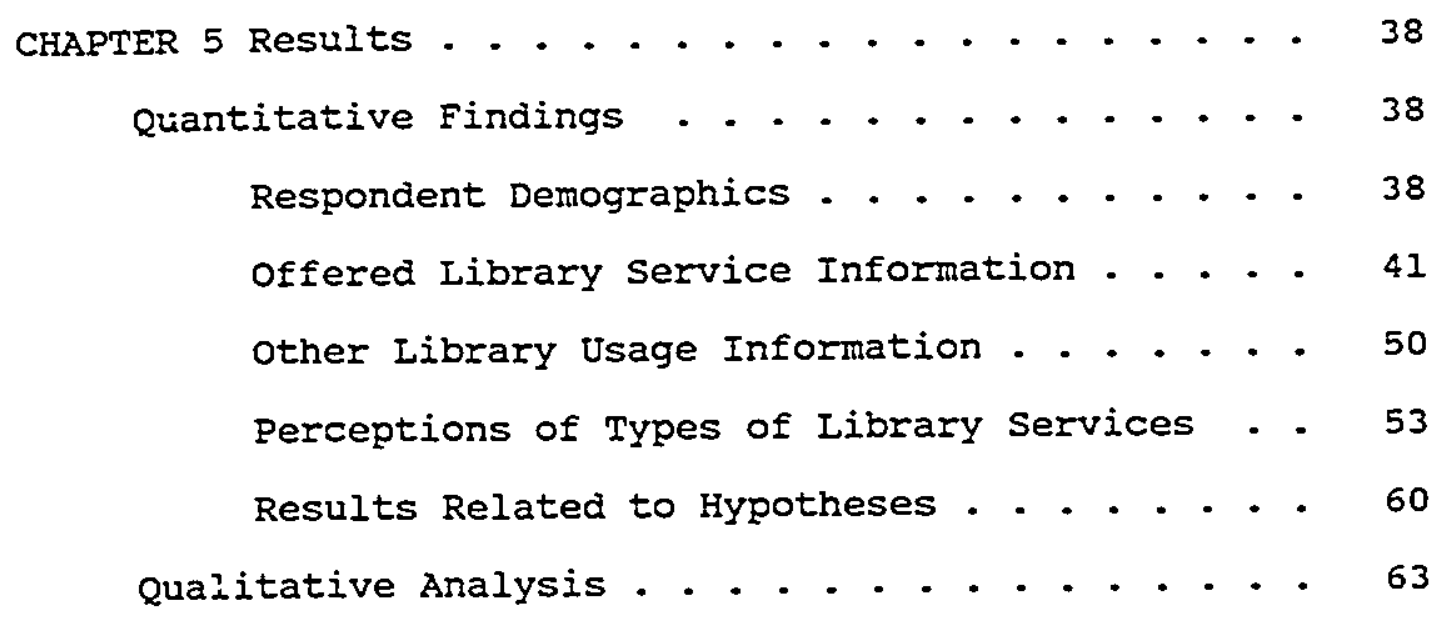

Chapter 6 Discussion . . . . . . . . . . . . 68

All Participants' Perceptions on Library Services 68

Site Response Comparison . . . . . . . . . . 69

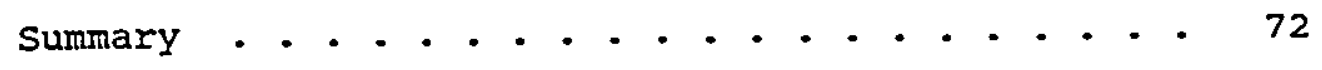

Iimitations . . . . . . . . . . . . . . 72

Survey Instrument . . . . . . . . . . 72

Survey Response Rate . . . . . . . . . 74

Further Study . . . . . . . . . . . . . . 74

References . . . . . . . . . . . . . . 76

Appendix A University of La Verne Survey Instruments • 79

Appendix B University of Phoenix Survey Instruments • • 91 $v i$ 
Appendix C Instructor Explanation Letter . . . . . 103

Appendix D All Grouping Responses to Survey Table on Library services . . . . . . . . . . . 104

Appendix E Student Grouping Responses to Survey Table on Iibrary Services . . . . . . . . . . 116

Appendix F Faculty Grouping Responses to Survey Table on Iibrary Services . . . . . . . . . . . 128

Appendix G Survey Respondents' Comments . . . . . 140 


\section{List of Tables}

Table

Page

1 Survey Response Rates . . . . . . . . . . 39

2 Degrees Student Respondents Were Pursuing . . . 40

3 Location Attending Classes . . . . . . . . . 40

4 Number of Classes Completed . . . . . . . . . 41

5 Informed About Service Frequencies . . . . . . . 42

6 Informed About Service - T-test . . . . . . . 42

7 Learned About Service Frequencies . . . . . . . . 44

8 Learned About Service - orientation - I-test . . . 44

9 Learned About Service - Personal Research T-test . . . . . . . . . . . . 45

10 Learned About Service - Librarian Presentation -

T-test .............. 45

11 Learned About Service - Wasn't Informed - T-test . 46

12 Learned About Service - Staff Members - T-test . . 47

13 Use Offered Service .. . . . . . . . . . 48

14 Used offered Service - T-test . . . . . . . . 49

15 Faculty Encouragement to Use offered Service -

T-test . . . . . . . . . . . . 50

16 Use Libraries other Than offered Service . . . . 51

17 Types of Other Libraries Used . . . . . . . . 51

18 Faculty Encouragement to Use other Libraries -

T-test ............ . . 53 
19 Services Offered Library Service Does Provide T-test . . . . . . . . . . . 56

20 Services offered Iibrary Service Should Provide T-test . . . . . . . . . . . . 56

21 Services offered by a Traditional University Library - T-test . . . . . . . . . . 57

22 Ranking of Value of Electronic Library Services only . . . . . . . . . . . . . 58

23 Ranking of value of Traditional Library Services only .................. . . 58

24 Ranking of Value of Both Services Combined . . . 59

25 Value of Both Services Combined - T-test . . . . 59

D-1 Library Services the Offered Service Does Provide . . . . . . . . . . . . . 104

D-2 Library Services the offered Service Should Provide . . . . . . . . . . . . 108

D-3 Library Services A Traditional University Library provides . . . . . . . . . . . . . 112

E-1 Library Services the Offered Service Does provide . . . . . . . . . . . . 116

E-2 Library Services the offered Service Should Provide . . . . . . . . . . . . . 120

E-3 Library Services A Traditional University Library Provides . . . . . . . . . . . . . 124 
F-1 Library Services the Offered Service Does

Provide . . . . . . . . . 128

F-2 Library Services the Offered Service Should

Provide . . . . . . . . . 132

F-3 Library Services A Traditional University Library

Provides ........... 136 
C:IAPTER I

Introduction

Electronic searching of online and CD-ROM databases, document delivery via data transmission or telefacsimilie $(f a x)$, and interactive media are indicators that the virtual library, a library where users have electronic access to a larger amount of information than is physically present, is a reality. Technology has affected the way information transactions are completed and will change libraries, library professionals and information services in directions only now imagined. As technology advances, debates about the future value of the traditional library, a physical repository of information and knowledge, flourish.

Traditionally libraries have had three essential ingredients: collections, buildings to house the collections, and staff (Robinson, 1992). Library users come to the library to satisfy all types of information-related needs. Patricia Glass Schuman stated, "Libraries are service organizations. Librarians are service-oriented professionals. The mission of librarians is not just to simply fill specific information needs. Our mission is to solve information problems" (1990, p. 38). The desire to solve these information problems quickly and efficiently has made the use of technology-mediated library services an attractive evolution for the profession. However, in the 
evolution of these technology-mediated services, the focus of the organization and profession is shifting from service to self-service with the unsupported assumption that this amounts to an improvement of position (Nelson, 1992). Traditional Iibraries offer: a vast amount of information both electronic and that which has not been (and may never be) converted to electronic form; a chance to browse and select materials in a hands-on manner; a collection that has many formats and varieties of information; and professionals to assist and guide users in their search for information.

Traditional libraries use consistent systems to provide access and store information. Cataloging methods are standardized and used in libraries world-wide. This allows users known and dependable methods to access the information available in the library. once learned, these access methods can be utilized by information seekers for old and new information. The information seeker does not need to learn a new system each time new informaticn is published. Technological advances have made it unnecessary for seekers of information to utilize the traditional library to access and obtain material each time they have an information need. As electronic information increases and becomes easier to access and search, there are more sources seekers zan approach to procure information. 
Individuals, with no specialized library training, can use computer technology to access and locate information. Information seekers, via microcomputer and modem, can directly access electronic information. The user of electronic information services can describe the information request to either the computer of a search intermediary (a person performing the search) and wait for the information to be delivered. Material that is found can be delivered in a variety of methods: printed as the information is transmitted; downloaded onto computer disk; or ordered for delivery by postal service or fax. The entire information transaction can take place without the seeker going to the traditional library or using traditional resources of the library.

Totally electronic libraries, libraries where there are no paper sources, only electronic ones, are starting to take the place of the traditional library. Electronic libraries are on college campuses across the nation. The twenty-first California state university campus is proposed to open in the fall of 1995 at Fort ord in Monterey County without a traditional library. Students will gain access to materials online (Freeberg, 1993). Although the California State University's Chancellor, Barry Munitz, did not say there will be no books on the shelves of the new campus, he did indicate, "there certainly won't be hundreds of thousands of 
books stored in the middle of the campus on shelves" (Freeberg, 1993, p. A1). Universities once boasted of the number of libraries on their campuses and the number of volumes on their shelves, but they may soon be taking pride in proclaiming just the opposite--how few books they contain and how much information is stored on computer disks. Electronic libraries offer: computer access to multiple sources and enormous amounts of information; connection to world-wide information sources; almost instantaneous retrieval of information; and different forms of information--citations, abstracts or full text immediately retrieved by the computer. A search performed electronically is not as physically labor intensive, nor as time consuming, as a search performed in a traditional Iibrary using traditional methods.

In contrast to traditional library systems, electronic information has neither standard search languages and protocols nor indexing standards at this time. Each electronic service has a unique search language that users must learn. Indexing methods and terms used in one database may not be used in another. The indexing process is usually not performed by following structured guidelines so chances of indexing errors are increased. These elements make systematic information retrieval of electronic data difficult. 
As electronic sources of information and access to these sources become available through electronic and technology-mediated Iibraries and other means, what is the perceived value and purpose of the traditional library to information seekers? If an information seeker has access to electronic library and information services, will he/she cease using the traditional library? Can technologymediated library services full $\ddot{y}$ satisfy information needs?

This study examined and compared two academic environments that offer technology-mediated library services to students and faculty. One university offers totally technology-mediated, electronic library services and the other offers technoiogy-mediated, eiectronic services supported by a traditional library and library services. Through survey of a stratified cluster sample of students and faculty from these two private institutions, the University of La Verne, off-site Campuses in Southern Salifornia and the University of Phoenix, Southern California campus, this study attempted to determine if, in these academic environments, technology-mediated library service had replaced the traditional library in function, value and satisfaction. The study also attempted to discover the purpose, value and services that students and faculty in these environments felt the traditional library offered and to determine if all or a portion of these 
functions were needed in addition to the offered technologymediated library services.

To determine if technology-mediated Iibrary services had replaced traditional ibraries and their services in function, value and user satisfaction in these settings, this study sought to answer the following descriptive questions about each site:

1. How often is the current service used?

2. Does the service provide enough information to satisfy the user's information need?

3. Is a traditional library used in addition to or in place of the current service?

4. What is the perceived value of both electronic services and traditional libraries individually and combined?

5. Would it be desirable to add more traditional library services to current services?

HYPOTHESIS ONE:

Technology-mediated library services do not replace the function of traditional library services for academic users.

- Additionally, this study sought to determine if the responses from University of La Verne students and faculty, who receive electronic services supported by a traditional library with a librarian who makes class visits and faculty contacts, would be significantly different than responses from University of Phoenix students, who receive total technology-mediated service with little or no librarian contact. This researcher proposes that although technology 
mediated library services are valuable, they will not replace traditional libraries and services in function, value or user satisfaction and there should be a significant difference in the responses from the two sites. In order to empirically test this theory, the following hypothesis was constructed.

HYPOTHESIS TWO:

There will be no difference between sites in:

A. usage of offered service and other libraries. B. level of satisfaction with the final form provided. C. encouragement by faculty to use offered service and other Iibraries.

This research provided an opportunity to study and compare two environments that are taking advantage of technology to provide library service.

These settings could be paradigms for libraries of the future as this technology-mediate:" electronic library era progresses. Responses from these environments will be valuable to the library profession in shaping this evolution so information needs can be met and libraries can clarify their value in the information society. 
CHAPTER 2

\section{Literature Review}

A search of online databases and indexes such as ERIC, IISA, Information Science Abstracts and Iibrary Literature by the author, uncovered no studies that dealt directly with library users' perceived value of traditional library services or technology-mediated library services. In a review of Iibrary literature in general, the author also could not determine any other research attempts to study user satisfaction with technology-mediated Iibrary services, similar to those utilized by the University of La Verne and the University of Phoenix.

The studies that were found that related to this subject fall in two categories: technology use and Iibrary facilities and service use. By refining these broad topics to technology use relating to: online public access catalogs (OPACs) (Bates, 1990; Cherry, 1992; Ensor, 1992; Peters, 1989), end users (Arnold, 1987; Burris \& Molinek, 1991; Friend, 1985; Kupferbert, 1986; Ojala, 1985; Wozny, 1988), and distance/off-campus education library facilities and service use (Cookingham, 1982; Miller, Johnson \& Shorland, 1984; Slade, Whitehead, Piovesan \& Webb, 1986), the author was able to gain some understanding of how library users have functioned with library technology, how distance/off- 
campus education environments provide Iibrary services and how these services are used.

\section{Technology Use}

Technology and technology-mediated library services are the dominant topics in today's Iibrary and information field. Milo Nelson stated, "Most of the presentations at conferences devoted to information and communications, education and computer applications, assume that once America is fully wired and networked, habits of learning and procedures of scholarship will be put on a sort of selfservice basis" (1992, p. 17). A review of literature about technology use in OPACs and end user searching indicated that the self-service mode has been in existence for some time. The degree of success with the technologies have been varied, and improvements continue to be needed (Arnold, 1987; Bates, 1990; Burris \& Molinek, 1991; Cherry, 1992; Ensor, 1992; Friend, 1985; Peters, 1989; Wozny, 1988). online Public Access Catalogs

Until recently, technology was used by library staff to maintain the collection, and it benefitted the institution rather than the user (Robinson, 1992). The development and wide-scale use of the online public access catalog (OPAC) began the shift from viewing technology as an internal tool to a tool to solve user information problems. Frederick 
Kilgour was an early proponent of the theory that the OPAC should be designed solely for the user, and during the l980s studies were conducted to determine what OPAC users liked and disliked (Duval \& Main, 1992). As a result of these studies, OPACs were developed to become user friendly, menu driven systems appeared, screens were designed to be easily read by the users, and online help sections were added to the programs.

Research is still underway that will inform designers how to build the perfect retrieval system. Marcia Bates wrote in 1990, "Much of the advanced research and development of automated information retrieval systems to date has been done with the implicit or explicit goal of eventually automating every part of the process" (p. 575). Because users have had trouble using searching systems, the technological goal would be to design systems in which the user has either no, or only reactive, involvement in the search process (Bates, 1990).

Although the information profession was willing to empower the library user with OPAC technology, the success with which the end users can operate the technology is questionable. In 1989, Thomas Peters conducted a study to determine the success rate of OPAC searchers on the University of Missouri's IUMIN system. For this study the transaction $\log$ of the system was analyzed to determine, 
anong other things, the failure rate or zero hits on searches performed during a 202-day period. The findings were that "failure rates were consistently high; they did not vary much from month to month or from terminal to terminal" (Peters, 1989, p. 270). The failures were mainly due to operator or user errors, usually in the areas of misspelling and typographical errors.

The development of keyword and Boolean searching was a development that would enable users to perform their own subject searches. This has also proved to be a disappointment for end users. A study conducted by Pat Ensor at Indiana State University found that, "contrary to some Iibrarians' beliefs a great majority of users are not embracing keyword searching whole-heartedly" (1992, p. 217). Ensor found one of the main frustrations of users was that they could not find the right words to define their topic. Cherry (1992) found that users' difficulties with subject searches could be attributed to the fact that most end users have little to no knowledge of subject headings and how they are constructed.

Iibrarians tried to solve end user searching problems by implementing training sessions. The profession hoped that proper training would insure end user searching success. Unfortunately, this strategy had its drawbacks. Peters (1989) stated, "It is amazing that OPAC users 
willingly spend hours learning the intricacies of software they want to use on their personal computers, but they grow impatient spending five minutes learning the basic commands and structure of an online catalog in the library" (p. 272). online Searcher - End User

Another technological step forward came with the wide spread use of telecommunications technology. At first, this technology was used to speed internal operations like cataloging and interlibrary loan. About 23 years ago, libraries began taking advantage of bibliographic networks for shared cataloging. Telecommunications technology linked large libraries to form networks for resource sharing. Libraries were also able to use telecommunications to access remote databases with stored indexing information to millions of journal citations (Mitchell \& Saunders, 1991). Professionals soon saw telecommunications and the advancing technology as another opportunity to solve users' information problems. This technology could make the user of the information the searcher of the information--the end user. (Here end user is defined as an online searcher who is not a librarian.) In 1981, Steve Goldspiel, Vice President of Marketing for Disclosure online database, verbalized this future shaping of users with the comment, "There are end users out there all right. They just don't know who they are" (Arnold, 1987, p. 71). 
Technological developments in microcomputers also helped spur the end user vision. Ojala (1985) wrote that it was estimated by the late 1980 s that 35 to 40 percent of office workers would have a personal computer. The information profession foresaw a more educated user, and the self-service vision was clear. Librarians also foresaw online databases as the perfect tool for users to achieve this vision, another technology-mediated library service to solve users' information problems.

End user online searching had implementation problems. It was expensive and, especially in the early stages, complicated. Although the service was available through librarians who acted as search intermediaries, few libraries could afford to offer online searching as an end user service. The introduction of online services like BRS/After Dark and DIALOG's Knowledge Index and the development of CD-ROM technology began to address the problems (Friend, 1985). The cost factor could begin to be contained. In fact, CD-ROMs became more cost effective each time they were used. This enabled the library to market and promote a service that it perceived users, both new and old, wanted. End user searching became an accepted and expected part of the library (Burris \& Molinek, 1991).

Libraries and information centers now examined how to fully develop end user services. As Burris and Molinek 
(1991) indicated, the problems associated with management and implementation of end user services were of prime concern. Much of the literature focuses on the internal impact and demands on the library. Demands included: staff knowing about hardware, software, CD-ROMs and online services; funding to provide these services; and staff to provide user training.

In the mid to late 1980s, studies began to examine the end user and the online searching process to determine how they were holding up. Kupferberg interviewed six end users and found, "Professionals who conduct their own online searching say that they're doing just fine" (1986, p. 24). However, other researchers found that the end user was having problems. Friend found that, "users, who may feei that computer programming expertise will suffice for database searching as well, are unlikely to perform efficiently or effectively without the requisite background knowledge that experienced librarian/searchers are qualified to supply" (1985, p. 140). Friend also pointed out that novice users will more than likely experience problems with: lack of access to detailed manuals and thesauri; problems with choice of terminology; lack of proper understanding of Boolean operators; lack of information on how to make a search more precise; system problems; or minimal information in the end user system manuals supplied by the vendors. 
Wozny (1988) conducted a study that examined several end user factors, one of which was if students actually used online search results in papers. She found that users had difficulty developing their search strategy and only 25 percent of the students included references from the search in their papers.

Wozny's study also touched on a topic that still causes end users' problems--locating the information once the citation has been found. Forty percent of the 36 students who participated in Wozny's study did not locate materials from their searches in the library. Those who did find materials often looked beyond the university Iibrary.

These findings would indicate that, although information professionals are interested in technologymediated library services to solve users information problems and develop self-service systems, end users were and are experiencing problems and frustrations. Peters pointed out in his study on the IUMIN system, "Public users" attitudes about LUMIN are generally positive, but how long will users continue to be enthusiastic about a tool that functions as intended only 60 percent of the time at best?" (1989, p. 271) Although this study referred specifically to the OPAC, the essence of the statement could apply to any of the technology-mediated services discussed. Iibrary users have been required to use technology-mediated services 
by the library and information profession. As the studies have shown, there have been times of problems and frustrations.

Future End User Services

Technology allows libraries to evolve in parallel with

new information sources. The virtual library that is developing is a decentralized collection of resources, individuals and systems that can all be accessed electronically (Paster \& Osif, 1992). Users will continue to come to the library with information needs, and the technology to access the information will continue to be an important part of the library's purpose.

The focus is now on networking technology to provide access to information for library users with the intent of making information access an end user service. Many libraries provide dial-up service to their OPACs, which in turn may provide access to the Internet, a computer network that connects computer networks around the world. The resources and information available through the Internet are immense. The Internet provides access to full text documents, a wide variety of databases, library OPACs, and services like CARL's (Colorado Alliance of Research Libraries) UNCOVER where a user requests an article and CARL, for a fee, delivers the article. 
As with the previous technology-mediated services, history is repeating itself with technology-mediated document delivery service. Mitchell and Saunders (1991) ccmmented that the CARI document delivery service would not soon replace traditional public services because most users were not sophisticated enough to take advantage of it. Libraries, however, continue moving toward replacing traditional services with technology-mediated services.

\section{Distance/Off-Campus Education}

Even though there are problems, technology-mediated library services have offered benefits and opportunities to bring basic or improved library services and access to populations that have previously been under-served. students and faculty who function in university distance/off-campus education programs are two such underserved groups. Distance/off-campus educational programs offer the opportunity to fill the educational needs of people away from the main campus. Offering library services in these programs is an important part of these students' education and of support of the faculty. Distance/C.f-Campus Libracy Services

By examining reports on distance/off-campus programs, the author was able to gain an understanding of how library services are delivered in distance/off-campus situations. The reports reviewed examined library services offered by 
California State University (CSU), Chico (Cookinghan, 1982), universities in the Canadian province of British Columbia (Slade et al., 1986) and the University of Wyoming (UW) (Miller et al., 1984).

In these three cases, the examination, provision and evolution of distance/off-campus library services was driven by the increasing popularity of this mode of education delivery. By 1981, csU, Chico's program had tripled in size and prompted the library reference department to realize alternative methods of delivering library services to remote sites (Cookingham, 1982). Miller et al. (1984) found, in the study of off- and on-campus library services at the University of Wyoming, that the level of off-campus activity had resulted in growing demand for University library services to be extended throughout the state in support of individual courses and the extended degree programs. During academic year 1983-84, approximately 11,000 students participated in UW extension and external degree programs, and 10,200 students were enrolled in the main campus in Laramie. In British Columbia's open Learning Institute (an institution that delivers courses entirely by distance education methods), courses offered swelled from seven in 1979 to 159 in 1985 (Slade et al., 1986). In British Columbia, the University of British Columbia, the University of Victoria, Simon Fraser 
University and the Open Learning Institute committed themselves to providing a broad range of library services for their off-campus students. Slade listed the following traditional and technology-mediated components that each university offered: core collections--books and articles provided by the University Library for use at the course site; special telephone Iines--used by off-campus students to request materials and information from the main campus: loans of specific materials--specific books or articles requested by off-campus students are sent from the main campus by mail; reference queries--reference questions and requests for literature searches are accepted from offcampus students at the main campus; interlibrary loans-interlibrary loans are processed at the main campus for offcampus students; and computer literature searches--online searches are conducted at the main campus for individual off-campus students for a modest fee. Advertisement of the services and bibliographic instruction were also listed as important components.

In 1980 Robert Cookingham, Visiting Librarian, CSU, Chico, indicated that awareness, access and availability of services, to faculty and administration, as well as students, were very important factors in off-campus library services. CSU, Chico library staff met regularly with faculty and administration to determine what materials and 
resources would be needed to meet the curriculum of offcampus courses or other types of information requirements. Library staff members also visited off-campus classes regularly to make students aware of the services offered. Cookingham listed the components of CSU, Chico's offcampus library services as: access tools--indexes, print, microform and online, placed at local library sites for offcampus students' use; special telephones--at local sites so off-campus students can contact the main campus; loan of main campus materials to off-campus students--materials are delivered by the most efficient delivery method available; reference services--off-campus students can access main campus reference services; interlibrary loan--initiated at the local site for CSU, Chico off-campus students; computer online searches--requested from the main campus via phone: and dial-up, keyboard access of CSU, Chico's catalog-selected local sites have access to CSU, Chico's online catalog.

In the review of the University of Wyoming report, it was more difficult to determine exactly what library services were being offered to distance/off-campus students. General references were made to the following services while reporting the results of the survey. The library services mentioned were: UW materials located at local libraries-materials were provided to ?ocal Iibraries for use by off- 
campus students; loan of main campus materials--specific materials were loaned by the main campus to off-campus students and delivered via mail; bibliographic database searching--the main campus performs online bibliographic database searches for off-campus students (Milier et al., 1984). Miller also noted that on- and off-campus students seem unaware of the services available to them and there is a need to advertise and inform students of services.

The review of these reports made it possible for the author to conclude that although methods vary slightly, services were similar and technology was used as a tool in delivery of these services. Local libraries, usually nonacademic, served as a valuable traditional resource to students in this environment, and all universities initiated cooperative services that benefitted these local libraries. For example, CSU, Chico offered libraries that participated in online searches for off-campus students free subject searches for non-off-campus students. They also provided interlibrary loans of CSU, Chico materials to any patron of those Iibraries (Cookingham, 1980). The University of Wyoming housed materials in local libraries that can be used by UW students or local patrons (Miller et al., 1984).

Finally, all of the reports examined indicate there was a problem in making students aware these services and resources exist. The need for librarians and library staff 
members to visit classes, instructors and administrators to inform and educate them about the library services was emphasized.

Distance/Off-Campus Use Study

Miller et al.'s (1984) study was of particular interest because it examined the library usage patterns and perceptions about library services of off-campus, nontraditional students (University of Wyoming Extension and University of Wyoming-Casper) versus on-campus, traditional students (University of Wyoming-Laramie). This study found that although traditional students use libraries other than university libraries only occasionally, a large portion of non-traditional students used public libraries rather than academic Iibraries.

This study also determined that students were not aware of the library services the University of Wyoming was offering. Miller reported that over half of all respondents at all sites indicated they had not received information concerning library services. At the time the study was done a large percentage of the off-site respondents indicated they did not know about or need the database search services available through the University of Wyoming Library or the library materials the University of wyoming had placed at local public, school or community college libraries throughout the state. Miller concluded that the University 
of Wyoming needed to improve information and awareness about library services to students and faculty members, as well as increase and improve the services.

Technology is being used to service users in an environment where they were historically under-served. The obligation of libraries has inherently been to provide information services to support the educational endeavors of the nembers of their respective communities. To do this Cookingham (1982) stated, "As librarians, we understand an individual's need for information. What we must do is to make everyone aware of libraries. Next we have to assure our potential patrons that libraries, library resources, and librarians are accessible. Then, ultimately, we must build the networks to provide fast, reliable delivery of materials when they are identified and needed by our library patrons" (p. 17).

The virtual, self-service, library without walls would be very beneficial in distance/off-campus environments. However, it is clear from past and present research, that users do not easily adjust to these technology-mediated, self-service enviroments. User awareness of services and ability to understand how these services will be beleficial is lacking.

Research on information seeking behavior has shown that people still prefer interpersonal sources over print and 
that they often expose themselves to new media products on recommendations from others (Dervin, 1989; Durrance, 1992). This information combined with the above information, indicates that technology-mediated library services are important and valuable, especially in the distance/offcampus educational environment. However, library users still need the more traditional approach to information retrieval/delivery--personal service and assistance. Providing access means more than making information available. The information profession needs to put more emphasis on the human dimensions of information use (Jackson, 1986).

As indicated previously, no studies were found that addressed the perceived value of traditional library services or technology-mediated library services or studies comparing usage of these services. This study attempted to discover the users' perceived value of these services by examining use patterns, user satisfaction with results and opinions about both types of services. 
CHAPTER 3

The sites

This study utilized survey results from students and faculty at two universities, the University of La Verne and the university of Phoenix, to determine what this population felt the service, value and purpose of a traditional library is. Survey information was also gathered to determine if this population felt the technologically-mediated library services they receive replaces in function, value and satisfaction of traditional library services.

Both universities have developed distance, off-campus programs to serve working adults in locations convenient to their home or work. Although the library programs are different at each university, they take advantage of similar electronic technology to offer library and information services to the student population and faculty members.

University Background

The University of Ia Verne

The University of La Verne (ULV), in La Verne, California, is an independent, non-sectarian institution of higher education founded in 1891 and is accredited by Western Association of Schools and Colleges. ULV is composed of four colleges: Arts and Sciences; Graduate and Professional Studies; Law; and Continuing Education. 
Bachelor's, master's, and doctoral degrees are offered to approximately 6,000 students.

In 1969, ULV began offering off-campus degree programs through the school of Continuing Education. These programs provide people an opportunity to enroll in Ia Verne programs at locations that are convenient to their homes or work. There are three divisions in the school of continuing Education: Professional Development Centers; La Verne College of Athens, Greece; and Residence Centers. Ia Verne College of Athens, Greece offers students the opportunity to pursue an American education in Athens, Greece. Residence Centers offer programs on selected military bases in California, Alaska and Italy.

The Professional Development Centers offer programs throughout California and consist of:

The Campus Accelerated Program for Adults (CAPA), a Central Campus program designed for working adult students. This program offers courses on evenings and weekends. Education Programs, provides advising and support for students pursuing an Master of Education, Educational Management; Preliminary Administrative Services Credential; Master of Science, School Counseling; and/or Pupil Personnel Services Credential at selected locations throughout California. 
Inland Empire Center, Orange County Center, San Fernando Valley Center, and Ventura County Center provide advisement and support for approximately 3,600 ULV students in these geographical areas. Degrees available at Center locations include: Bachelor of Science, Accounting; Bachelor of Science, Business Administration; Bachelor of Science, Healthcare Management; Bachelor of Science Public Administration: Master of Business Administration; Master of Science, Business organization Management; Master of Business Administration for Experienced Professionals; and Master of Health Administration. Each Center does not offer all programs. However, all offer Bachelor of science, Business Administration; Bachelor of Science, Public Administration; and Master of Business Administration for Experienced Professionals or Master of Business Administration. Programs are delivered in a quarterly 10week format.

The University of Phoenix

The University of Phoenix (UOP) is a private, degreegranting institution, accredited by the North Central Association of Schools and Colleges in 1978, whose mission is to serve working, adult students. Educational programs and services are provided to over 20,000 students at 27 campuses and learning centers in Arizona, California, Colorado, Hawaii, Nevada, New Mexico, Utah and the 
Commonwealth of Puerto Rico through comprehensive education delivery, quality control, and learning outcomes assessment systems.

UOP offers associate's degrees, bachelor's degrees in business, management and nursing and master's degrees in business, management, education, counseling, nursing administration, and computer information systems. Not all degrees are offered at each site. Programs are delivered in accelerated formats.

The structure of the University of Phoenix, Southern California consists of Learning Centers in Fountain Valley, Van Nuys, South Bay, Diamond Bar, individual group classes held at sites convenient to students where Learning Centers do not currently exist and at Edwards Air Force Base. The student population on the Southern California Campus at the time of the study was approximately 3,200 .

Students at the Southern California Campus follow a pre-set schedule of classes to obtain a Bachelor of Science, Business Administration; Bachelor of Arts, Management; Bachelor of Science, Nursing; Master of Business Administration; Master of Arts, organizational Management; and Master of Nursing with specialization in Administration/Management. 


\section{Iibrary Services}

The University of La Verne

The University of Ia Verne's library services to offcampus students and faculty are supported by a traditional academic Iibrary, The Elvin and Betty Wilson Iibrary. This library contains 160,000 volumes, 1,000 current journal subscriptions, films and filmstrips, video and audio cassettes, records, slides, tapes, and other media. Both campuses of the College of Law have a law library of over 90,000 volumes. Interlibrary loan and reciprocal borrowing privileges at other academic libraries are available.

School of Continuing Education (SCE) students/faculty may use any of the Campus libraries and the wilson Library catalog is on CD-ROM and available in all permanent SCE centers. Each SCE center also has a reading room with a collection of current journals that pertain to the programs offered at that center.

off-Campus Library Services are offered to all SCE students and faculty. The students and faculty can call a toll free number to request information. An off-campus Library Services staff person will help define the information request, explain how the search will be conducted, why one resource might be selected over another, how the search results will be delivered and how to request the desired articles, books or materials found in the search 
results. Search results, full-text (if available) and books will be sent to students via mail.

The off-Campus Library Services Librarian makes regular visits to Centers to inform the students about the available service and how to use it. The Librarian also has regular contact with faculty and works with them to help with information needs they or their students might have. The University of Phoenix

The University of Phoenix offers library services through Learning Resource Services. Learning Resource Services functions as an electronic library and is housed at the University of Phoenix headquarters in Phoenix, Arizona. Unlimited electronic searches are prorided to students and faculty through Academic Information Service (AIS). Information about Learning Resource Services is presented to students at orientations and through faculty members. Faculty members are informed about the LRS during a five week training session.

Information searches are requested by phone, telefax or mail. Learning Resource Assistants help the requestor define search topics by phone. Online searches are completed and printouts of retrieved bibliographic citations and abstracts are sent to the requestor by mail or fax, if the requestor has indicated the information is needed immediately (only the first twenty pages will be faxed). 
Students/faculty members then secure the desired items on their own or request full-text copies of the artisles from Learning Resource Services. If full-text is requested, copies of articles are made either from the collection of approximately 750 microfiched journals to which the University of phoenix subscribes or a by commercial vendor. 
CHAPTER 4

Method

To gather the information on users' perceived value of traditional and technology-mediated library services, use patterns and user satisfaction with service results, the survey method of research was used. Survey methodology is used to determine opinions, attitudes, preferences and perceptions of participants in a study (Borg, Gall \& Gall, 1992). The descriptive information gathered by the surveys used in this study helped to define how users of technologymediated library services felt about the offered services and traditional services and if the offered services satisfactorily replaced the traditional library and traditional library services.

It was important to ensure that students from both academic levels (undergraduate and graduate), from each of the participating centers and at different points of program completion were included in the study. The stratified sampling procedure ensures that individuals of a population who have certain characteristics are represented in the sample. Cluster sampling uses a naturally occurring group of individuals, like a class (Borg, Gall \& Gall, 1992). For these reasons a stratified cluster sample from the population was used to measure student perceptions about the 
traditional library service and technologically-mediated Iibrary service.

\section{Study Participants}

Students enrolled in the undergraduate and graduate level business programs at the University of Phoenix, Southern California (excluding Edwards Air Force Base) and University of La Verne Centers: Inland Empire, Orange County, San Fernando valley and Ventura County, were the population for this study. These programs were selected because they are offered at all of the locations and the coursework required to obtain the degrees were similar at each institution. The author has no reason to believe that students enrolled in these programs would be unique in their use of the offered library services or other resources. Classes held at military installations were excluded from this study because resources available at military bases vary significantly.

The entire population of faculty members that teaches at ULV Centers and YOP Southern California were included in the study.

\section{Erocedure}

\section{Sample selection}

Student. The student stratified cluster sample consisted of three undergraduate and three graduate classes selected from each Center. The sample from each Center 
contained one undergraduate and one graduate class that was beginning, mid-point, and completing the programs. A random class from one off-site location in each area served by a Center was also included in the sample.

The stratified cluster sample was selected from centerbased and off-site students enrolled in undergraduate and graduate business programs at ULV, SCE Centers and UOP, Southern California. Center managers reviewed class Iists and selected samples to meet the criteria set by the author. This resulted in a sample size of 830,432 from ULV and 398 from UOP.

Faculty. Each university provided mailing lahels for the faculty members that participated in the study. The total number of faculty members that received surveys was 581, 137 from ULV and 444 from UOP. Survey Design and Testing

The survey instruments for students and faculty were designed by the author. The instruments were reviewed by the author's thesis committee and each participating university. Revisions were made, and the instruments were field tested using one class from the health/nursing program at the University of Phoenix and two faculty members who would not be participating in the study from the University of La Verne. The class and faculty members that tested the instr ment were selected by each university. 
The survey instruments were customized to reflect each university's and Iibrary service's name. ULV student and faculty surveys referred to the library service as offCampus Library Service (see Appendix A). UOP student and faculty surveys referred to the library service as Learning Resource Service/Academic Information Service (IRS/AIS) (see Appendix B). Student surveys at both universities contained the same questions, as did faculty surveys.

Survev Distribution/Administration

Student. Each university administered the surveys to the sample classes. At UOP, the student surveys were delivered by the author to the Center. Each Center placed the survey packets in the classrooms for the instructor to administer. The author contacted each faculty member by telephone to explain the study and provided each faculty member with an information sheet (see Appendix c) that explained the purpose of the study. After the surveys were completed, the instructor collected the surveys and returned them to the Center Manager, who returned them to the author. At ULV, the student surveys were sent to the off-Campus Librarian, who distributed them to the Centers. Each Center placed the survey packets in the classrooms for the instructor to administer. The off-Campus Librarian contacted each faculty member by telephone to explain the study and each faculty member was provided the information sheet that 
explained the purpose of the study. After the surveys were completed, the instructor collected the surveys and returned them to the Center Manager, who returned them to the offCampus Librarian, who forwarded them to the author.

Faculty. Each faculty member was mailed a cover letter, the faculty survey and a postage-paid, selfaddressed return envelope. The cover letter (samples in Appendixes $A$ and $B$ ) explained the purpose of the study and requested that the faculty member complete the survey and return it to the author in the enclosed envelope. Quantitative Data Analysis

Frequency distributions were run and means calculated on all questions to gather descriptive statistics. Cronbach's Alpha was used on responses from All Grouping to determine item reliability for the survey question that requested respondents to compare electronic library services with traditional library services (question 17 on student survey and question 14 on faculty survey) and the table on the survey that requested respondents to select services that are provided, should be provided and traditional university services (question 18 on student survey and 15 on faculty survey). Once reliability was established scales were constructed by summation. 
Student t-tests were run on each question to determine if response differences of the groupings were significant. Data were tested and analyzed by the following groupings:

All Grouping - all ULV respondents compared with all UOP respondents

Student Grouping - ULV student respondents compared with UOP students

Faculty Grouping - ULV faculty respondents compared with UOP faculty respondents

Qualitative Data Analysis

Respondents' comments from survey questions that provided an opportunity to select "other" and write in comments (questions 6,9 , and 17 on the student survey and questions 3,6 , and 14 on the faculty survey) and the final question that asked participants for additional comments (question 22 on the student survey and question 19 on the faculty survey) were examined to determine patterns in responses. These comments were grouped and studied to determine if conclusions about perceptions of the offered service and value of electronic (technology-mediated) and traditional library service might be drawn. 


\begin{abstract}
CHAPTER 5
Results

Data gathered from the surveys were analyzed to

determine if the hypotheses for this study should be accepted or rejected and to gather general information about how study participants perceived and valued the current electronic, technology-meditated service and traditional library services.
\end{abstract}

\title{
Quantitative Findings
}

The quantitative findings were grouped into sections pertaining to respondent demographics, offered service information, other library usage, and perceptions of types of library services. Respondent Demographics

Student Respondents. The response rate to the survey was similar between the sites and groups (see Table 1). An examination of the demographic data available revealed no information that would indicate there were demographic differences between respondents other than where they attended school. 
Table 1

Survey Response Rates

\begin{tabular}{lccc}
\hline & Number of & Number of & \\
Surveys & Percentage \\
Respondents & Surveys Sent & Returned & Returned \\
\hline ULV Students & 432 & 209 & $48.3 \%$ \\
\hline ULV Faculty & 137 & 52 & $37.9 \%$ \\
\hline UOP Students & 398 & 213 & $53.5 \%$ \\
\hline UOP Faculty & 444 & 155 & $34.9 \%$ \\
\hline Total & 1,411 & 629 & $44.6 \%$ \\
\hline
\end{tabular}

The student demographic information showed most student respondents were pursuing undergraduate degrees (Table 2) and attended classes at centers (Table 3 ). As indicated in Table 4 , the greatest number of overall student respondents were mid-program, having completed more than three but fewer than ten classes. 
Table 2

Degrees Student Respondents were Pursuing

\begin{tabular}{|c|c|c|c|c|c|c|c|}
\hline \multirow{4}{*}{ Site } & \multirow{4}{*}{$\begin{array}{l}\text { Total } \\
\text { Rec'd }\end{array}$} & \multirow{2}{*}{\multicolumn{2}{|c|}{ Undergraduate }} & \multicolumn{4}{|c|}{ No } \\
\hline & & & & \multicolumn{2}{|c|}{ Graduate } & \multicolumn{2}{|c|}{ Response } \\
\hline & & Number & : & Number & $\vdots$ & lunber & 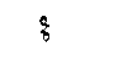 \\
\hline & & & of Total & & of Total & & of Total \\
\hline ULV & 209 & 163 & $77.9 \%$ & 44 & $21.1 \%$ & 2 & $1.0 \%$ \\
\hline UOP & 213 & 129 & $60.5 \%$ & 81 & $38.0 \%$ & 3 & $1.5 \%$ \\
\hline TOTAL & 422 & 292 & $69.1 \%$ & 125 & $29.6 \%$ & 5 & $1.3 \%$ \\
\hline
\end{tabular}

Table 3

Location Attending Classes

\begin{tabular}{|c|c|c|c|c|c|c|c|}
\hline \multirow[b]{2}{*}{ Site } & \multirow{2}{*}{$\begin{array}{l}\text { Total } \\
\text { Rec'd }\end{array}$} & \multicolumn{2}{|c|}{ Center } & \multicolumn{2}{|c|}{ off-Site } & No & Response \\
\hline & & Nunber & $\begin{array}{c}\vdots \\
\text { of Total }\end{array}$ & Nuraber & $\begin{array}{c}3 \\
\text { of Total }\end{array}$ & Number & of Total \\
\hline ULV & 209 & 143 & $68.4 \%$ & 52 & $24.8 \%$ & 24 & $6.8 \%$ \\
\hline UOP & 213 & 112 & $52.5 \%$ & 93 & $43.6 \%$ & 8 & $3.9 \%$ \\
\hline TOTAL & 422 & 255 & $60.4 \%$ & 145 & $34.3 \%$ & 22 & $5.3 \%$ \\
\hline
\end{tabular}


Table 4

Number of classes Completed

\begin{tabular}{|c|c|c|c|c|c|c|c|}
\hline \multirow[b]{2}{*}{ Site } & \multirow[t]{2}{*}{$\begin{array}{l}\text { Total } \\
\text { Rec'd }\end{array}$} & \multirow{2}{*}{$\begin{array}{l}3 \text { or } \\
\text { luaber }\end{array}$} & \multirow{2}{*}{$\begin{array}{l}\text { Fewer } \\
\frac{a}{\text { of Total }}\end{array}$} & \multicolumn{2}{|c|}{$\begin{array}{c}\text { More Than } 3 \text {, } \\
\text { Fewer Than } \\
10\end{array}$} & \multicolumn{2}{|c|}{$\begin{array}{c}\text { More Than } \\
10\end{array}$} \\
\hline & & & & liunber & of Total & Nurber & of Total \\
\hline ULV & 209 & 45 & $21.5 \%$ & 98 & $46.9 \%$ & 57 & $27.3 \%$ \\
\hline UOP & 213 & 64 & $30.0 \%$ & 67 & $31.5 \%$ & 64 & $30.0 \%$ \\
\hline TOTAL & 422 & 109 & $25.8 \%$ & 165 & $39.1 \%$ & 121 & $28.7 \%$ \\
\hline
\end{tabular}

Faculty respondents. It was not possible to determine general demographic information about faculty respondents because 74 (36\%) did not complete the demographic information question on the survey. Those who did complete the question answered it in various ways, and it was difficult to group responses. offered Library service Information

Informed about offered service. As can be seen in Table 5, most respondents indicated they were slightly more informed than unsure (4) or unsure (3) about the offered service. A t-test on the AIl Grouping revealed that UOP 
participants felt better informed of the service than ULV participants (see Table 6). Individual grouping t-tests showed that the difference was also significant in the Student Grouping but not in the Faculty Grouping. Table 5

Informed About Service Frequencies

\begin{tabular}{cccccc}
\hline Sites & No & & Unsure & & Know All \\
& Idea & & & & About It \\
& 1 & 2 & 3 & 7 & 5 \\
\hline ULV & 54 & 24 & 70 & 77 & 29 \\
\hline UOP & 35 & 42 & 104 & 143 & 39 \\
\hline TOTAL & 89 & 66 & 174 & 220 & 68 \\
\hline
\end{tabular}

Table 6

Informed sbout Service - T-test

\begin{tabular}{lcccccc}
\hline Grouping & $t$ & df & p* & $\begin{array}{c}\text { Significant } \\
Y / N\end{array}$ & ULV & UOP \\
& & & & Mean & Mean \\
\hline All & 3.4 & 623 & $<.05$ & $Y$ & 2.94 & 3.28 \\
\hline Student & 4.1 & 418 & $<.05$ & $Y$ & 2.89 & 3.38 \\
\hline Faculty & .1 & 203 & $>.05$ & $\mathrm{~N}$ & 3.16 & 3.15 \\
\hline
\end{tabular}

*two-tailed 
Learned about offered service. The largest number of respondents indicated that they had learned about the existing service through orientation information, flyers/handouts, and university staff members. As can be seen in Table 7 , several respondents indicated they were not informed about the service.

As shown in Tables 8 and 9 , t-tests indicated UOP participants learned of the service through orientations and personal research more often than ULV participants. These difference were also reflected in the individual groupings, except in the case of faculty personal research where the difference in responses was not sijnificant.

The All Grouping ULV respondents indicated they learned of the offered service through Iibrarian presentation more often than UOP respondents (see Table 10). The responses were not significantly different in testing the student Grouping on this item, but the difference was reflected when the Faculty Grouping was tested.

UIV participants indicated they were not informed of the service more often than UOP participants. This differeirce was reflected when the student Grouping was tested, but not in the Faculty Grouping (see Table 11). 
Table 7

Learned About Service Frequencies

\begin{tabular}{|c|c|c|c|c|c|c|c|c|}
\hline Sites & $\begin{array}{c}\text { Orienta- } \\
\text { tion }\end{array}$ & $\begin{array}{l}\text { Elyers/ } \\
\text { Bandouts }\end{array}$ & Staff & $\begin{array}{l}\text { Personal } \\
\text { Research }\end{array}$ & Librarian & Faculti & Students & $\begin{array}{c}\text { lot } \\
\text { Inforaed }\end{array}$ \\
\hline ULV & 59 & 81 & 81 & 22 & 31 & 69 & 44 & 54 \\
\hline UOP & 212 & 122 & 122 & 49 & 13 & 93 & 69 & 31 \\
\hline TOTAL & 271 & 203 & 203 & 71 & 44 & 162 & 113 & 85 \\
\hline
\end{tabular}

Table 8

Learned About Service - orientation - T-test

\begin{tabular}{lcccccc}
\hline Grouping & $t$ & df & $p *$ & $\begin{array}{c}\text { Significant } \\
\text { Y/N }\end{array}$ & ULV & UOP \\
& & & & Mean & Mean \\
\hline All & 9.6 & 605 & $<.05$ & $Y$ & .23 & .60 \\
\hline Student & 9.6 & 413 & $<.05$ & $Y$ & .23 & .66 \\
\hline Faculty & 3.3 & 190 & $<.05$ & $Y$ & .25 & .52 \\
\hline
\end{tabular}

*two-tajled 
Table 9

Learned About Service - Personal Research - T-test

\begin{tabular}{|c|c|c|c|c|c|c|}
\hline Grouping & $t$ & df & $p *$ & $\begin{array}{l}\text { Significart } \\
\qquad / \mathbb{N}\end{array}$ & $\begin{array}{l}\text { ULV } \\
\text { Mean }\end{array}$ & $\begin{array}{l}\text { UOP } \\
\text { Mean }\end{array}$ \\
\hline All & 2.1 & 605 & $<.05$ & $Y$ & .09 & .15 \\
\hline Student & 2.7 & 413 & $<.05$ & $Y$ & .08 & .17 \\
\hline Faculty & .3 & 190 & $>.05$ & $\mathbf{N}$ & .13 & .11 \\
\hline \multicolumn{7}{|c|}{ Table 10} \\
\hline \multicolumn{7}{|c|}{ Learned About Service - } \\
\hline \multirow[t]{2}{*}{ Grouping } & $t$ & $d f$ & $\mathrm{p} *$ & Signiricant & ULV & UOP \\
\hline & & & & $Y / N$ & Mean & Mean \\
\hline All & 3.0 & 605 & $<.05$ & $Y$ & .12 & .05 \\
\hline student & 1.8 & 413 & $>.05$ & $\mathbf{N}$ & .08 & .04 \\
\hline Faculty & 5.1 & 190 & $<.05$ & $Y$ & .33 & .06 \\
\hline
\end{tabular}

‡two-tailed 
Table 11

Learned About Service - Wasn't Informed - T-test

\begin{tabular}{lcccccc}
\hline Grouping & $t$ & df & $p^{*}$ & Significant & ULV & UOP \\
& & & & $Y / N$ & Mean & Mean \\
\hline All & 4.2 & 605 & $<.05$ & $Y$ & .21 & .09 \\
\hline Student & 4.3 & 413 & $<.05$ & $Y$ & .21 & .07 \\
\hline Faculty & 1.6 & 190 & $>.05$ & $\mathrm{~N}$ & .23 & .13 \\
\hline
\end{tabular}

*two-tailed

Testing of the AII Grouping revealed no significant

difference in the responses regarding being informed of the service by staff members. However. as seen in Table 12, the Student Grouping test indicated UOP respondents learned of the service by staff members more often than ULV respondents. The Faculty Grouping test indicated the opposite, ULV faculty learned of the service from staff more often than UOP faculty. 
Table 12

Learned About Service - Staff Members - T-test

\begin{tabular}{|c|c|c|c|c|c|c|}
\hline Grouping & 2 & $d f$ & $p^{*}$ & $\begin{array}{l}\text { Significant } \\
Y / N\end{array}$ & $\begin{array}{l}\text { ULV } \\
\text { Mean }\end{array}$ & $\begin{array}{l}\text { UOP } \\
\text { Mean }\end{array}$ \\
\hline All & .8 & 605 & $>.05$ & $\mathrm{~N}$ & .32 & .35 \\
\hline Student & 2.5 & 413 & $<.05$ & $Y$ & .27 & .39 \\
\hline Fàculty & 3.1 & 190 & $<.05$ & $Y$ & .54 & .30 \\
\hline
\end{tabular}

*two-tailed

Description of offered service. Two hundred thirty-one respondents (ULV 54, UOP 177) described the existing library services as electronic library services--fax, computer, modem, on-line searching, telephone. Traditional and electronic library services was selected next frequently as the description of offered services (118; ULV 52, UOP 66 ;. Most respondents indicated that they did not use the offered library services or that they use the service occasionally (see Table 13). Only 25 participants (UIV 14, UOP 11) indicated they used the offered services regularly for most classes.

As seen in Table 14, a t-test on this question on All Grouping indicated no significant difference in responses about use of the service. However, t-tests on the other groupings (student and faculty) indicated there were 
significant differences. UOP student participants indicated they used the service more than their ULV counterparts and ULV faculty participates indicated they used the service more than UOP faculty participants.

Table 13

Use offered service

\begin{tabular}{|c|c|c|c|c|c|}
\hline \multirow[t]{2}{*}{ site } & \multirow[t]{2}{*}{$\begin{array}{l}\text { Number } \\
\text { Responding }\end{array}$} & \multicolumn{2}{|c|}{$\begin{array}{l}\text { Do Not Use } \\
\text { Service }\end{array}$} & \multicolumn{2}{|c|}{$\begin{array}{l}\text { Use Service } \\
\text { Occasionally }\end{array}$} \\
\hline & & llusber & $\begin{array}{l}\text { of Total } \\
\text { Responding to } \\
\text { Iten }\end{array}$ & Number & $\begin{array}{l}\text { : of Total } \\
\text { Responding to } \\
\text { Iten }\end{array}$ \\
\hline ULV & 261 & 135 & $51.7 \%$ & 89 & $34.0 \%$ \\
\hline UOP & 368 & 175 & $47.6 \%$ & 140 & $38.1 \%$ \\
\hline Total & 629 & 310 & $49.3 \%$ & 229 & $36.4 \%$ \\
\hline
\end{tabular}


Table 14

used offered service - T-test

\begin{tabular}{lcccccc}
\hline Grouping & $t$ & df & p* & $\begin{array}{c}\text { Significant } \\
\text { Y/N }\end{array}$ & $\begin{array}{l}\text { ULV } \\
\text { Mean }\end{array}$ & Mean \\
\hline All & .8 & 613 & $>.05$ & $\mathrm{~N}$ & 1.98 & 2.05 \\
\hline Student & 3.2 & 412 & $<.05$ & $\mathrm{Y}$ & 1.90 & 2.25 \\
\hline Faculty & 2.6 & 199 & -.05 & $\mathrm{Y}$ & 2.27 & 1.77
\end{tabular}

*two-tailed

of the respondents who did use the offered services, 128 (ULV 55, UOP 73) indicated they could use most of the information provided. Respondents indicated the most common final form of the information provided was a listing of references and article summaries (139; ULV 28, UOP 111). Journal/periodical article was the next most frequently selected item at 83 (ULV 51, UOP 32). T-tests did not reveal a significant difference in responses between groups. Most respondents (133; ULV 43, UOP 90) selected item (3) use the information in the form as it is provided and search for another form equal number of times. There was no significant difference in responses between groups.

Faculty encouragement to use offered service. As seen in Table 15, a t-test on the All Grouping revealed a significant diffurence in responses concerning faculty 
encouragement to use the service. UOP participants indicated more faculty encouragement to use the offered service than ULV participants. This difference was reflected in the student Grouping t-test but not in the Faculty Grouping t-test.

Table 15

Faculty Encouragement to Use offered Service - T-test

\begin{tabular}{lcccccc}
\hline Grouping & $t$ & df & p* & $\begin{array}{c}\text { Significant } \\
\text { Y/N }\end{array}$ & $\begin{array}{l}\text { ULV } \\
\text { Mean }\end{array}$ & $\begin{array}{l}\text { MoP } \\
\text { Mean }\end{array}$ \\
\hline AlI & 4.9 & 603 & $<.05$ & $Y$ & 2.32 & 2.84 \\
\hline Student & 4.0 & 411 & $<.05$ & $Y$ & 2.12 & 2.54 \\
\hline Faculty & .3 & 190 & $>.05$ & $\mathrm{~N}$ & 3.19 & 3.26 \\
\hline
\end{tabular}

Ætwo-tailed

other Iibrary Usage Information

Table 16 illustrates that a large portion of survey respondents indicated they regularly use other libraries. The two types of libraries most often used were public and university/college (see Table 17). Two hundred nineteen respondents indicated they had used a library other than the offered service six or more times in the past six months. 
Table 16

Use Libraries other Than offered Service

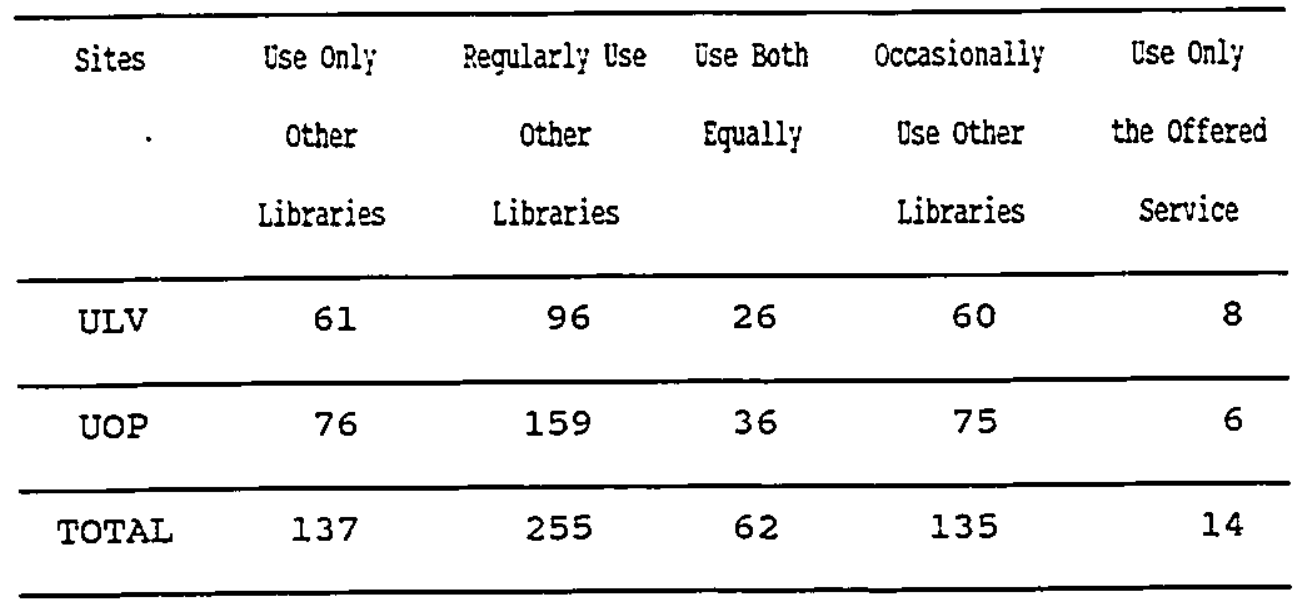

Table 17

Types of other Libraries Used

\begin{tabular}{lccccccc}
\hline Sites & $\begin{array}{c}\text { University/ } \\
\text { College }\end{array}$ & $\begin{array}{c}\text { Consunity } \\
\text { College }\end{array}$ & & Public Special & Electronic & other & $\begin{array}{c}\text { Does lot Apply, } \\
\text { Use Only offered } \\
\text { Service }\end{array}$ \\
\hline ULV & 74 & 27 & 135 & 9 & 1 & - & 8 \\
\hline UOP & 175 & 13 & 146 & 9 & 3 & 6 & 6 \\
\hline TOTAL & 249 & 40 & 281 & 18 & 4 & 6 & 14 \\
\hline
\end{tabular}

T-tests on all of the groupings did not reveal a significant difference in responses to this question. 
The three most frequently selected reasons for using other libraries were:

1. More convenient to use other Iibraries

(284; ULV 127, UOP 157).

2. Iike to browse collection (182; ULV 74, UOP 108).

3. Need to supplement materials proviced by offered service ( 174; ULV 65, UOP 109).

The three least frequently selected reasons for using other Iibraries were:

1. Material provided by offered service is not historical (8; ULV 2, UOP 6).

2. Material provided by offered service is not current enough (12; ULV 5, UOP 7).

3. Does not apply I use only offered service. (26; ULV 14, UOP 12).

A t-test on the AlI Grouping revealed a significant difference in responses regarding faculty encouragement to use other libraries (see Table 18). UOP participants indicated greater faculty encouragement to use other libraries than ULV participants. This was also reflected in the student Grouping t-test, but not in the Faculty Grouping t-test. 
Table 18

Faculty Encouragement to Use other Libraries T-test

\begin{tabular}{lcccccc}
\hline Grouping & $t$ & df & $p *$ & $\begin{array}{c}\text { Significant } \\
Y / N\end{array}$ & ULV & UOP \\
& & & & Mean & Mean \\
\hline All & 6.4 & 603 & $<.05$ & $Y$ & 2.42 & 3.13 \\
\hline Student & 5.9 & 408 & $<.05$ & $Y$ & 2.07 & 2.72 \\
\hline Faculty & .4 & 193 & $>.05$ & $\mathrm{~N}$ & 3.80 & 3.72 \\
\hline
\end{tabular}

Ætwo-tailed

Perceptions of Types of Library Services

Respondents were asked to compare electronic library services with traditional library services and select the items that most closely reflected their feelings about the service on question 17 of the student survey and question 14 of the faculty survey. Items one through five of this question were weighted in favor of electronic services and items six through eleven were weighted in favor of traditional services.

The three most frequently selected items were:

1. Electronic services make it easier for users to access information than traditional library services (270; ULV 100, UOP 170).

2. I feel comfortable using a traditional library (248; ULV 99, UOP 149). 
3. I feel comfortable using electronic services

(242; ULV 87, UOP 144).

Cronbach's Alpha was run on this question to determine the reliability of: if a respondent selected one item weighted toward a type of service, they would select all items that were weighted toward the similar service. The test resulted in an alpha of .70 on electronic library service (items 1-5) and an alpha of .64 on traditional library service (items 6-11). Once reliability was determined, a scale was constructed by summation. T-tests performed on the All Grouping of both the electronic Iibrary preference and traditional library preference revealed a significant difference between ULV and UOP participants only in electronic library preference $(\underline{t}(570)=2.0, \underline{p}<.05)$. The difference was due to UOP participants preferring electronic library services more than ULV participants (means $=1.59,1.34$ respectively) . All respondents were asked to complete a table by selecting what services were offered by their university, what services should be offered by their university, and what services a traditional university library offered. A large number of respondents (236) elected not to complete the DOES PROVIDE column. The SHOULD PROVIDE column was not completed by 284 respondents, and 335 did not complete the TRADITIONAL UNIVERSITY SERVICES COIUMn. 
The items selected most often in each of the three categories were:

DOES PROVIDE: Does searches on electronic databases for students for free (302; ULV 104, UOP 198).

SHOULD PROVIDE: Access to interlibrary loan

(175; ULV 65, UOP 110).

TRADITIONAL UNIVERSITY SERVICES: Access to librarians and

other information specialists on site

(212; ULV 64, UOP 148).

Cronbach's Alpha was run on these three categories.

The test resulted in a high alpha number for each category, $.90, .92$, and .93 respectively. This indicated that: if a respondent selected one item in a category, the reliability was very high that they selected all items in that category. A scale was constructed by summation once reliability was established.

A t-test performed on the All Grouping of these three categories (DOES PROVIDE, SHOULD PROVIDE, TRADITIONAL UNIVERSITY SERVICES) revealed significant differences between ULV and UOP participants in all three areas (see Tables 19, 20, and 21). 
Table 19

S. vices offered Library Service Does Provide T-test

\begin{tabular}{lcccccc}
\hline Grouping & $t$ & df & p* & $\begin{array}{c}\text { Significant } \\
Y / N\end{array}$ & ULV & UOP \\
& & & & Mean & Mean \\
\hline All & 6.2 & 386 & $<.05$ & $Y$ & 10.58 & 7.11 \\
\hline Student & 4.9 & 248 & $<.05$ & $Y$ & 10.57 & 7.00 \\
\hline Faculty & 3.6 & 136 & $<.05$ & $Y$ & 10.61 & 7.25 \\
\hline
\end{tabular}

*two-tailed

Table 20

Services offered Library Service should Provide T-test

\begin{tabular}{lcccccc}
\hline Grouping & $t$ & df & p* & $\begin{array}{c}\text { Significant } \\
\text { Y/N }\end{array}$ & ULV & UOP \\
& & & & & Mean & Mean \\
\hline All & 2.0 & 341 & $<.05$ & $Y$ & 10.28 & 8.73 \\
\hline Student & 1.7 & 223 & $>.05$ & $\mathrm{~N}$ & 10.65 & 9.07 \\
\hline Faculty & .2 & 116 & $>.05$ & $\mathrm{~N}$ & 8.50 & 8.26 \\
\hline
\end{tabular}

ॠtwo-tailed 
Table 21

Services offered by a Traditional university Library $T$-test

\begin{tabular}{lcccccc}
\hline Grouping & $t$ & df & p* & $\begin{array}{c}\text { Significant } \\
\text { Y/N }\end{array}$ & $\begin{array}{l}\text { ULV } \\
\text { Mean }\end{array}$ & UoP \\
& & & & & & \\
\hline All & 2.0 & 287 & $<.05$ & $Y$ & 12.18 & 13.94 \\
\hline Student & 1.1 & 165 & $>.05$ & $\mathrm{~N}$ & 11.21 & 12.47 \\
\hline Faculty & .1 & 120 & $>.05$ & $\mathrm{~N}$ & 15.47 & 15.34 \\
\hline
\end{tabular}

*two-tailed

T-test responses to table items for the All Grouping

are listed in Appendix D, Tables $D-1, D-2$ and $D-3$. Appendix $E$, Tables E-1, E-2 and E-3 list the t-test responses of the Student Grouping and Appendix F, Tables F-1, F-2 and F-3

list the responses of the Faculty Grouping.

Respordents were asked to rate the value of each type of service (electronic and traditional) separately and then the value of both services delivered together. The scale was ranked from no value (1) to very valuable (5). As Tables 22,23 , and 24 illustrate, most respondents rated each service separately as 4 and both services combined as 5. 
Table 22

Ranking of Value of Electronic Library Services only

\begin{tabular}{lccccc}
\hline Sites & No & & & & $\begin{array}{c}\text { Very } \\
\text { Valuable } \\
\end{array}$ \\
& 1 & 2 & 3 & 4 & 5 \\
\hline ULV & 13 & 14 & 59 & 87 & 57 \\
\hline UOP & 6 & 29 & 91 & 137 & 78 \\
\hline TOTAL & 19 & 43 & 150 & 224 & 135 \\
\hline
\end{tabular}

Table 23

Ranking of Value of Traditional Library Services only

\begin{tabular}{lccccc}
\hline Sites & No & & & & $\begin{array}{c}\text { Very } \\
\text { Value }\end{array}$ \\
& 1 & 2 & 3 & 4 & 5 \\
\hline Valuable & 9 & 13 & 59 & 96 & 56 \\
\hline UOP & 6 & 23 & 73 & 149 & 91 \\
\hline TOTAL & 15 & 36 & 132 & 245 & 147 \\
\hline
\end{tabular}


Table 24

Ranking of Value of Both Serri ses Combined

\begin{tabular}{|c|c|c|c|c|c|}
\hline \multirow[t]{2}{*}{ sites } & No & & & & very \\
\hline & Value 1 & 2 & 3 & 4 & Valuable 5 \\
\hline UIV & 4 & 4 & 27 & 72 & 124 \\
\hline UOF & 1 & 5 & 30 & 97 & 205 \\
\hline TOTAL & 5 & 9 & 57 & 169 & 329 \\
\hline
\end{tabular}

A t-test on the All Grouping disclosed a significant difference (see Table 25) in the value of both services combined. JCP participants placed more value on both services combined than ULV participants. T-tests on both other groupings (student and faculty) revealed no significant difference.

Table 25

Value of Botr Services combined T-test

\begin{tabular}{lcccccc}
\hline Grouping & $t$ & df & p* & $\begin{array}{c}\text { Significant } \\
Y / N\end{array}$ & ULV & UOP \\
& & & & Mean & Mean \\
\hline AII & 2.7 & 574 & $<.05$ & $Y$ & 4.24 & 4.45 \\
\hline Student & 1.2 & 380 & $>.05$ & $\mathrm{~N}$ & 4.14 & 4.25 \\
\hline Faculty & .8 & 192 & $>.05$ & $\mathrm{~N}$ & 4.63 & 4.73 \\
\hline
\end{tabular}

*two tailed 


\section{Results Related to Hypotheses}

Hypothesis one. Technology-mediated library services do not replace the function of traditional library services for academic users.

To determine if the null hypothesis should be accepted or rejected, the answers to five questions were analyzed.

How often is the current service used? Most of the respondents indicated that they did not use the offered service or used it occasionally. Only $4 \%$ (25) of the respondents indicated that they use the offered service regularly.

Does the service provide enough information to satisfy the users information need? The group of participants that did use the offered service indicated that they could use most of the information provided. Respondents indicated that the most common final form is a listing of references and article summaries. They used the information in the form it was provided and searched for other forms an equal number of times.

Is the traditional Iibrary used in addition to or in place off the current service? Most participants (93\%) indicated they use libraries other than the offered service and 219 (34.8\%) of these respondents used other library services six or more times in the last six months. Public anc university/college are the top two types of other libraries used. The most popular reasons for other 
library use are convenience, like to browse collections, and need to supplement materials provided by the offered service.

What is the perceived value of both electronic services and traditional libraries individualiy and combined?

Respondents valued services, electronic only and traditional only, equally--4 on a scale of no value (1) to very valuable (5). However, they rated both services combined as verv valuable (5).

Would it be desirable to add more traditional library services to current services? Participants who completed the table indicated some traditional library services should be added to the offered service. Access to interlibrary loan was the most requested arditional service. The responses to all of the five questions indicated that the null hypothesi- should be accepted, technologymediated library services do not replace the function of traditional library services for academic users.

Hypothesis Two. There will be no difterence between sites in:

A. usage of offered ser:ice and other libraries. B. level of satisfacticin with the final form provided. C. encouragement by faculty to use offered service and other libraries.

Responses from ULV students and faculty who receive electronic services supported by a traditional library and UOP students and faculty who receive technology-mediated 
services with little or no librarian contact were analyzed for significant differences in the above three areas.

Usage of offered service and usage of other libraries. There was no significant difference in responses to :sage of the offered services between all ULV respondents and all UOP respondents. However, there was a significant difference in responses about usage of the offered services when student and faculty responses were compared individually. UOP students used the offered service more than ULV students and ULV faculty used the offered service more than UOP faculty. There was no significant difference in responses between any of the groupings in the area of other library usage.

Level of satisfaction with the final form provided. A significant difference in satisfaction with the final form was not determined in responses from participants.

Encouragement by faculty to use offered service and other Iibraries. There was a significant difference in responses between universities regarding faculty encouragement to use the offered service and other library services. UOP participants indicated greater faculty encouragement in usage of both types of services than aid ULV participants.

The null hypothesis should be accepted for usage of the offered service and other libraries when data from all participants was used. The null hypothesis should also be 
accepted in all cases for the level of satisfaction with the final form provided.

The null hypothesis should be rejected in all cases for faculty encouragement to use the offered service and other libraries. It should also be rejected for usage of the offered service for individual group (i.e. students and faculty) comparisons.

\section{Qualitative Analysis}

Respondent comments were analyzed to determine patterns. The responses did not appear to be unique by university setting, so comments were reported as a whole, rather than comparing responses from groups. A listing of all comments is in Appendix G.

Participants wrote in comments on four questions:

1. How would you describe [offered library services]?

(Number 3 faculty survey and number 6 student survey.)

AlI four of the participant groups (ULV students, ULV faculty, UOP students, UOP faculty), wrote in 38 comments for this question. The most frequent responses from all participants were those that indicated they did not know about the service or had not used the service. Six participants indicated the type of service as: materials upon request; on-line ivll text periodicals and newspaper articles; limited periodical database; electronic 
library/fax; request over the phone and they fax or mail; or electronic access of various databases.

2. What is the final form (i.e. listing, article, book) you usually get from [offered library service]? (Number 6 faculty survey and number 9 student survey.) There were only six comments under this question. ULV faculty participants did not write in comments. The most frequent response was "not used" (2), with the other responses describing the final form as: information over the phone; copy of article; article; and index and abstract.

3. [Offered Iibrary service] is an electronic based service supported by traditional library services. If you were to compare electronic library services with traditional Iibrary services, please mark the comment(s) that most closely reflect how you feel. (Number 14 faculty survey and number 17 student survey.)

All but one of the comments to this question, came from UOP faculty and UOP students. ULV faculty had no comments and ULV students had only one response, "don't know about service."

The mont frequent responses from UOP students and faculty were that they did not use the service, did not know about the service, and cannot compare services. UOP student 
participants who were able to compare indicated they thought electronic services were faster and easier.

4. Do you have additional comments about electronic and traditional library services? (Number 19 faculty survey and number 22 student survey.)

one hundred and twenty-five comments were written-in responding to this questions. To determine if a pattern appeared in the comments, the responses were grouped by participating group (i.e. ULV students, ULV faculty, UOP students, UOP faculty) under headings that broadly defined the responses.

The first heading was Usage/Knowledge of Service. The main theme of these comments were about participants lack of knowledge, lack of publicity, or lack of use of the service. Several indicated the need for training about the service. Twenty-six comments were grouped under this heading and of the 26,22 referenced these four areas.

The next heading was Favorable comments About the offered service. Of the fifteen comments under this heading, eight weie from ULV student participants. Comments indicated participants liked the service because they did not have to go to the Iibrary themselves. The service was a time-saver that allowed students to concentrate on work at home. 
Under the heading Unfavorable comments About offered Service, there were 30 comments, two of which were from UIV faculty participants. only four of the comments were from ULV students, the remaining 24 from UOP faculty and students. Most of the comments indicated that the service was too slow, too confusing, and not marketed well. UOP student participants indicated a desire to have the entire magazine or copy of an article available, and the cost of obtaining these items being less.

Under the heading Favorable Comments About Electronic Services there were 15 comments, with none from ULV faculty participants. The theme of these comments indicated that most participants felt library services were moving toward more electronic services. They indicated they liked the speed at which information can be found and electronic services are more convenient. The high cost for these services was mentioned, with the desire to have costs decrease.

There were only six written comments under the heading Unfavorable comments about Electronic services. ULV faculty had no comments under this heading. Comments referred to the high costs of the servicos and it is difficult to define the scope of a search.

The heading Favorable comments Traditional Iibrary Services contains eight comments. Most of these indicated 
participants feel more comfortable using traditional libraries. One participant pointed out that some traditional libraries provide electronic services for their users.

There were no comments that would be grouped under a heading Unfavorable Comments Traditional Library Services. The next heading was comments on Both services

Combined. No ULV students had comments that grouped under this category, and UOP students accounted for only two of the ten written-in responses. Faculty participants indicated the combination of both types of Iibrary services as positive.

The last heading was comments About the Survey. Most of the comments under this section indicated that the survey was too Iong. 


\section{Chapter 6 \\ Discussion}

The purpose of this study was to attempt to discover if technology-mediated electronic library service had replaced traditional Iibrary services in function, value and satisfaction in two academic settings. To accomplish this, data were analyzed with two goals: first, to determine how all participants perceived technology-mediated, electronic library services and traditional library service; and second, to compare responses from each site for significant difference, to determine if ULV participants (who receive a technology-mediated, electronic service supported by a traditional Iibrary) responses would reflect the difference in service type.

The findings of this study indicate that although students and faculty members in both universities had access to electronic, technology-mediated library services they still continue to use the traditional library. Technologymediated services have not replaced traditional library services in these settings.

\section{A1] Participants' Perceptic. in Library Services}

Most of the survey respondents did not use the offered services. They used other types of libraries regularly. Respondents that used the offered services searched for other forms of the information equally as often as they used 
the form provided by the service. Information seekers in these two settings indicated that it was more convenient to use other libraries and that they liked to browse the collections of a traditional library. A portion of other library use may be attributed to participants lack of knowledge about the offered services. Most of the respondents indicated that their knowledge about the service was $\underline{4}$ on a scale where $\underline{3}$ was unsure. This lack of confidence and knowledge about the services could contribute to other library usage.

Respondents completing the compar: a table indicated traditional library services should be added to the current service. They choose having professionals to assist and guide users most often as the feature that defines a traditional university library.

Participants valued each type of library service, but find both types combined very valuable.

\section{Site Response Comparison}

These findings indicated that as an entire group, there was not a significant difference in the way ULV and UOP participants used other libraries, the offered services or satisfaction with the final form provided by the service. The fact that the ULV service is supported by a traditional library did not significantly affect the way ULV participants responded when compared to UOP participants. 
ULV respondents indicated more services were provided by their offered service. They also indicated more services should be provided. ULV respondents indicated, as did UOP respondents, access to interlibrary loan as the number one service the university should provide. However, ULV does provide interlibrary loan access for their off-site students.

UOP participants indicated more services are provided by a traditional library than ULV students. Additionally, UOP participants valued both types of library service combined more highly than did ULV participants. This difference could be because ULV students receive more traditional library services with the ULV offered service than UOP participants and expect those basic services to be offered as part of library services.

All participants use other libraries regularly, more participants don't use the offered service than do, and they use the final form and search for other material an equal number of times.

Usage of the offered service did vary by grouping. UOP students use the offered service more than their ULV counterparts. This difference could de attributed to UIV students indicating they were less informed about the service than UOP students. However, the fact that ULV participants used the service less than UOP participants 
refutes the author's supposition that :echnology-mediated services supported by traditional library services would facilitate more usage of the service.

UIV faculty members use the offered service more than their UOP counterparts. Faculty members at ULV indicated they had learned about the service from librarian presentations. This personal, face-to-face contact could account for the difference in the way faculty at both sites use the offered services.

Reported faculty encouragement to use the offered services and other libraries also varied significantly. Faculty members at UOP encouraged use of the offered service more than faculty at ULV. This cannot be attributed to UOP faculty feeling more informed of the service, because there was no significant difference in this area. Faculty at ULV use the offered service themselves more than UOP faculty, so it seemed curious to the author that they did not recommend the service to students.

Reported faculty encouragement to use othor libraries was also greater among UOP participants. This encouragement could be because UOP has fewer traditional services available and they feel, as ULV faculty do, that traditional services are important.

The findings would not seem to support the author's supposition that ULV participants would be more satisfied 
with the offered service than UOP participants. There was not a significant difference in usage of other libraries or satisfaction with the final form.

\section{Summary}

The issues that appeared most often in this study were participants feeling unsure or uninformed about the offered services and they do not use the services. The comments indicated that training about the service and how to use it would be helpful for students and faculty in both settings. Participants also indicated there should be more marketing/publicity of the services.

User awareness and training were also issues in earlier studies on distance education library services (Cookingham, 1982; Miller, Johnson \& Shorland, 1984; Slade, Whitehead, Piovesan \& Webb, 1986) and technology-mediated library service such as online public access catalogs (OPACs) (Cherry, 1992; Ensor, 1992; Peters, 1989), and end users (Friend, 1985; Wozny, 1988) that were reviewed for this study. The findings of this study support the previous study findings that user awareness and training need to be a prior:t.- when delivering technology-mediated services.

\section{Iiritations}

\section{Survey Instrument}

Although the survey instruments were tested and reviewed, survey respondents indicated they were too Iong. 
Some problems also surfaced when analyzing the results. If this study were to be replicated, steps should be taken to correct the following problems.

A large portion of survey respondents (38\%) chose not to complete the table that was analyzed to determine if participants knew what services the offered service provided; what traditional library services they felt should be added to the current service; and what services a traditional university library offered.

After testing, the reliability was found to be high that if a respondent selected one iten in a column they selected all. This indicated participants did not make discriminating choices when completing the table.

These points would indicate the table was too confusing and complicated for participants to complete and reduced the amount of zeliable data retrieved from this section.

Faculty mailing lists from two ULV Centers were not obtained. This contributed to ULV faculty responses being low. However, the number of responses returned by faculty members versus those sent was similar between the universities (UIV $37.9 \%$; UOP $34.9 \%$ ).

Faculty respondents did not answer the question on the survey designed to gather demographic information. This question was not presented in a way that clearly directed 
respondents as to what type of information should be entered.

\section{Survey Response Rate}

The averaged response rate for this study was $44.6 \%$. This low response rate could be expected for the faculty surveys that were self-returned. However, the student surveys were directly administered. A higher response rate may have been experienced if the author wou?d have administered all of the surveys, rather than delegating this function.

There was no information that would lead the author to believe that non-respondents had a higher or lower level of awareness of the offered library services.

\section{Further study}

This study examined two universities that rely on technology to deliver library services to their students and faculty. Although the findings of this study were similar to those found in earlier studies about distance education library services and technology-mediated library services concerring low usage rate and awareness of the offered service, it clearly indicated that library service users are becoming more educated about technology-mediated servires.

The participants of this study valued the combination of both types of services higher than they valued each individually. This study showed that although technology- 
mediated services have not replaced traditional library services in these setting, respondents were aware of the difference in the services and the advantages both provide. A replication of this study in a traditional academic setting could help determine if the use and awareness problems disclosed in this study are unique to distance/offcampus education settings or if these are general problems the entire academic library community faces. Further studies on student and faculty awareness, value and use of technology-mediated and traditional library services would be desireable because it would provide information that could advance user-driven utilization of technology-mediated library services and enhance user satifaction of these services.

The use of technology to deliver library services is going to continue. As seen in this study, the values of these services are acknowledged. However, the delivery and implementation of these type of services require extensive and careful planning to ensure that the user is satisfied with the product. 
References

Arnold, S. E. (1987, January). End-users: Dreams or dollars. online, 11, 71-78.

Bates, M. J. (1990). Where should the person stop and the information search interface start? Information processing \& Management, 26, 575-591.

Borg, W. R., Gall, J. P. \& Gall, M. D. (1993). Applying Educational Research: A practical guide. (3rd ed.) White Plains, NY:Longman.

Burris, R. A. \& Molinek, F. R. (1991, March). Establishing and managing a successful end-user search service in a large special library. Online, 15, 36-39.

Cherry, J. M. (1992, May). Improving subject access in OPACs: an exploratory study of conversion of users' queries. The Journal of Academic Librarianship, 18(2), 95-99.

Cookingham, R. M. (1982, October). Delivering off-Campus Library services in Northern California. Paper presented at the off-Campus Library Services Conference, St. Louis, MO. (ERIC Document Reproduction Service No. ED 223 253)

Dervin, B. (1989, summer). Users as research inventions: How research categories perpetuate inequities. Journal of communication, $39(3), 215-232$.

Durrance, J. C. (1989, Spring). Information needs: Old song, new tune. School Library Media Quarterly, 17, 126-130.

Duval, B. K. \& Main, L. (1992). Automated Library Systems. Westport, CT: Meckler.

Ensor, P. (1992, September). User practices in keyword and boolean searching on an online public access catalog. Information Technology and Libraries, 11(3), 210-219.

Friend, L. (1985, July). Independence at the terminal: Training student and end users to do online literature searching. The Journal of Academic Librarianship, $11(2), 136-141$. 
Freedberg, L. (1993, July 15). Cal State's next campus a library with on-line books. San Francisco Chronicle. p. Al.

Jackson, M. M. (1986, Spring/Sumner). Everybody needs information. Reference Librarian, 14, 133-139.

Kupferbert, N. (1986, March). End-users: How are they doing? a Iibrarian interviews six "do-it-yourself" searchers. online, 10, 24-28.

Miller, K. A., Johnson, J. S. \& Shorland M. D. (1984, September). Library User and Preferences: A Comparison of on-campus and off-campus students at the University of Wyoming. Paper presented at the Articulation Conference on Library Services to offCampus Students, 2nd Jackson Research Center, WY. (ERIC Document Reproduction Service No. ED 2556 348)

Mitchell, M. \& Saunders, L. M. (1991, April). The virtual library: An agenda for the 1990s. Computers in Libraries, 11, 8-11.

Mitchell, M. \& Saunders, I. M. (1991, September-October). The evolution of library automation: Libraries and telecommunications. Library software Review, 10(5), 342-343.

Nelson, Milo. (1992, December). "At the workstation and in the wilderness: the new scholarship." Information Today, $9,17+$.

ojala, M. (1985, spring). End user searching and its implications for librarians. Special Libraries, 76, 93-99.

Paster, A. \& Osif, B. (1985, Fall). Great expectations: Satisfying today's patrons. Special Iibrarians, 83, 195-199.

Peters, T. A. (1989, November). When smart people fail: An analysis of the transaction $\mathrm{log}$ of an online public access catalog. The Journal of Academic Librarianship, $\underline{15}(5), 267-273$.

Robinson, C. (1992, March 15). The public library vanishes. Library Journal, 117, 51-54. 
Schuman, P. G. (1990, March 1). Reclaiming oux technological future. Library Journal, 115, 34-38.

Slade, A. L., Whitehead, M., Piovesan, W., \& Webb, B. (1986). The Evolution of Library Services for offCampus and Distance Education students in District Columbia. Victoria. B. C., Canada: University of Victoria Library. (ERIC Document Reproduction Service No. ED 278 418)

Wozny, I. A. (1988, Fall). College students as end user searchers: one university's experience. $\underline{\mathrm{R} O}, \underline{28}, 54-$ 61 . 
Appendix A

University of Ia Verne Survev Instruments

\section{SIEn SAN Nose

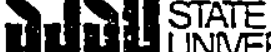

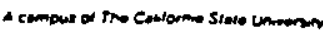

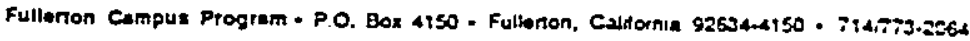

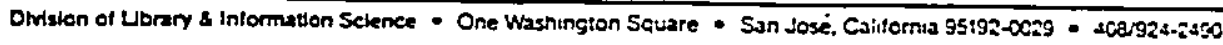

Dear University of La Vezne Student:

I am a graduate student enrolled in the Librayy and Information Science progran at San Jose State University, Eullerton Campus and have elected to write a thesis to complete my studies.

My thesis explores the perceived value and purpose of the traditional library as electronic sources to information, and access to these sources, become available outside the traditional librazy. The University of Phoenix and University of la verne take advantage of these advances to offer technologicallyenhanced electronic library services to their students and have agred to participate in this study.

To gather the information, a sample of students in the business programs of both universities will be surveyed. It is anticipated that none of the questions on this survey have the potential to cause harm or discomfort to participants. Nor will the study have a direct benefit or risk to any of the pazticipants. The zesults of this study may be published, but any information that could result in the identification of participants will remain confidential.

Your class has been selected as part of the sample. You should understand that the participation of students is voluntary and that choosing not to participate in this study, or in any part of this study, will not affect your relations with the University of Ia Verne, the University of Phoenix or San Jose State University.

Could you please take a few minutes to complete the attached survey? The survey should be returned to your instructor when you have finished.

If you have questions about this study, I will be happy to talk with you. I can be reached at (714) 649-3092. If you have questions of complaints about research subjects' rights, or in the event of a research related injury, please contact serena Stanford, Ph.D., Associate Academic Vice President of Graduate Studies and Research at (408) 924-2480.

sincerely,

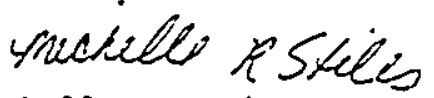

Michelle R. Stiles 


\section{IIPFARY SERVICES SUTRVEY}

1. What degree are you pursuing at the University of Ia Verne?

2. Do you attend classes in a Learning Centez? __ Yes _ No

3. How many classes have you completed at the unive: ity of La Verne?

4. How weli informed do you feel you are of the librazy services (OffCampus Library Services) provided by the University of Ia verne (UIV)? (circte one)

No Idea that It Is ${ }^{2} \quad \begin{aligned} & 3 \\ & \text { Unsure }\end{aligned}$

5. How did you leara about off-campus Iibrary Services? (check all applicable)

orientation information

flyers/handouts

ULV staff

personal research librarian presentation

instructors

other students

wasn't informed of service

6. How would you describe off-campus Iibrary services' services? (check one) traditional ibrary services--books. periodicais, reference services, databases, personal assistance electronic library services--fax, computer, moden, on-iine searching, telephone traditionai and electronic library services other

7. How often do you use off-campus Library Services? (check onte)

1. Do not use

2. Tried one time, won't use again

3. Use occasionaliy, depends on class

4. Use regularly for most classes

5. Use for every ciass

8. Does the information you receive from off-campus Library Services satisfy your information need? (check one)

1. No, could not use any of the information provided

2. No, could not use most of the information provideo

3. Used some--didn't use some

4. Yes, can use most of the information provided

5. Yes, can consistently use all of the information provided

6. Not applicable, don't use service

9. What is final form (i.e. Iisting, article, book) you usually get from off-Campus Library Services? (check one)

book

journa l/periodical article

iisting of references and article summaries

listing of references

other

Not applicable, don't use service 
10. Does the final form of the information, as indicated in the previous question, provided by off-Campus Library Services mee youz needs? (check one)

1. No, I can never use the information in the form provided. I must do a total new search on my own.

2. No, I usualiy can't use the information in the form provided. I use the information to find the suitable form on my own.

3. I use the information in the form as it is provided and search for another form equal number of times.

4. I usually use the information in the form provided. Very seldom do I search for the information on my own.

5. I consistentiy use the information in the form provided by 0if-Campus Library Services.

6. Not appiicable, I don't use service.

11. Do ULV instructors encourage you to use off-Campus Library Sezvices? (check one)

1. No, never

2. A few of my instructors have

3. Some have, some haven't ... its equa 7

4. Most of my instructors have

5. All of my instructors have

12. Do ULV instructors encourage you to use othez libraries? (check vne)

1. No, never

2. A few of my instructors have

3. Some have, some haven't -- its equal

4. Most of my instructors have

5. All of my instructors have

13. Do you use libraries other than the services of off-Campus iibrayy Services? (check one)

1. Yes, I only use other libraries

2. Yes, I regularly use other i ibraries

3. I use other libraries and off-Campus Library Services equaliy

4. I occasionally use other libraries

5. No, I only use Off-Campus Library Services

14. If you use libraries other than off-Campus Library Services, what type of library do you use most often? (check one)

University/College

Community College

Public

Special (Law, Medical, etc.)

Electronic

Other

Does Not Apply

15. In the past six months, how often have you used a library other than off-Campus Library Services? (check one)

Not at all

Once

Twice

Three Times

Four times

Five times

Six times or more 
18. Please mark the services you understand that off-Canpus librazy Services currentiy provide, any service you think it should provide and services you would expect to find at a traditional academic library - a California State University Libzary, for example. (check as many as apply in each column)

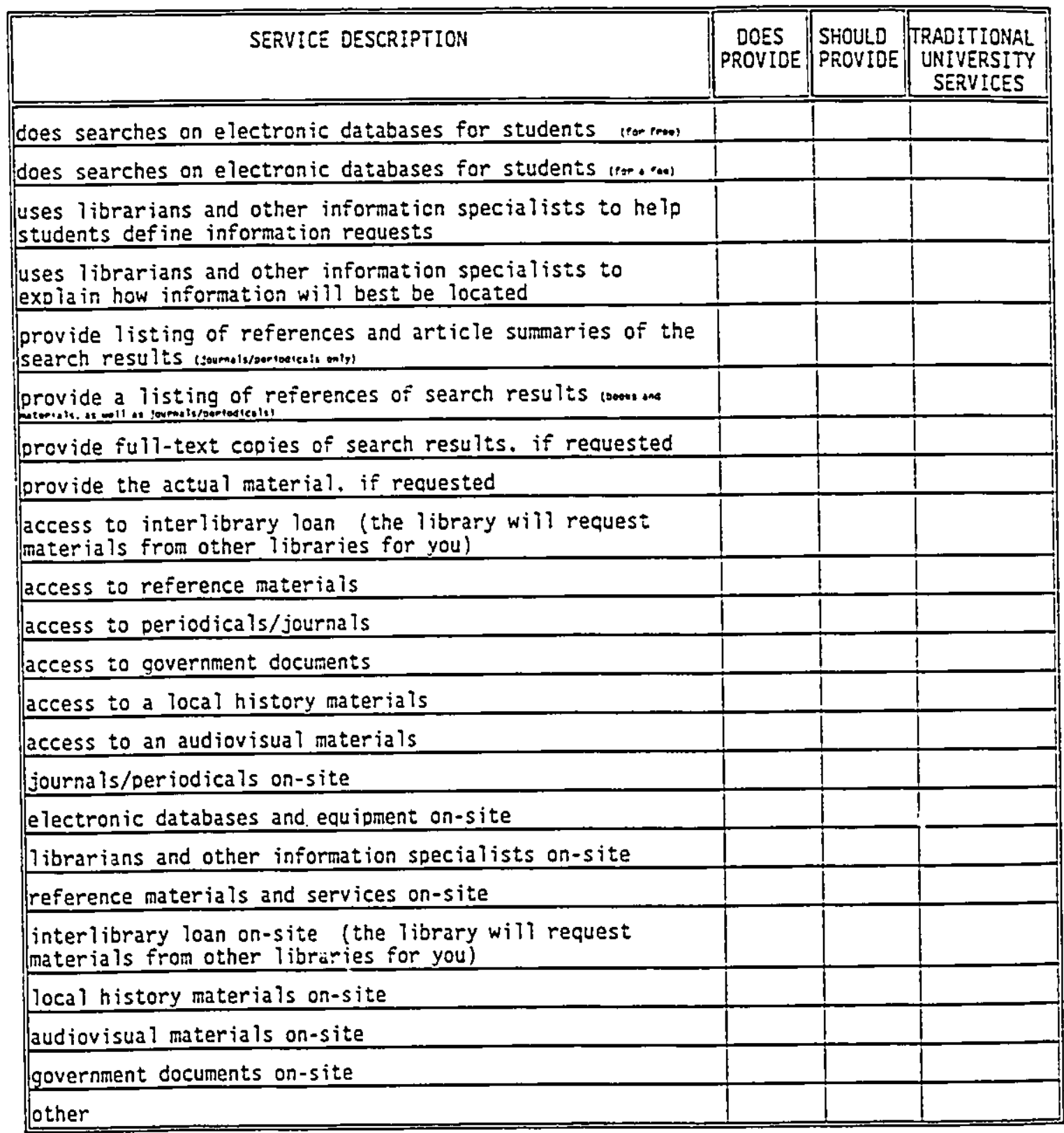


16. If you use Iibraries other than off-campus Iibrazy services, what is the reason? (check as many as apply)

Would rather do my own research

Materials provided by Off-Campus Library Services are not what is needed

Need to suppiement materials provided by off-Campus Library Services

More convenient to use other Tibrary

Off-Campus Library Services takes too long to supply information

Want to talk to a person face-to-face to request information

Need actuai materials instead of copies of articles

Material provided by off-Campus Library Services not current enough

Material provided by Off-Campus Library Services not historical

Like to browse a collection

Like to do my own electronic searches

Want to do an extensive search of all types of materiai

Unsure how to use the service

Does not apply, I only use Off-Campus Library Services.

17. Off-Campus Iibrary Services is an electronic based sezvice suppozted by traditional library services. If you were to compare electronic library services with traditional iibrary services, please aar the comment(s) that most closely reflect how you feel. (check as many as apply)

Electronic services make it easier for users to access information than traditional services.

Electronic services enable users to access more information than traditicnal services. I feel comfortable using electronic services.

I would rather use electronic services than the traditional library.

I feel more comfortable asking for help with electronic services than with traditional library services.

Traditional iibrary services offer greater varieties of information then electronic services.

Traditional libraries provide access to more information than just electronic services.

I feel confortable using a traditional library.

feel comfortable asking for help in a traditional ibrary.

I can find what I want most of the time in a traditional library.

I would rather use a traditional library than electronic services.

other 
Please circle the number which nost closely reflects your feelings about:

19. The value of only electronic library services (library services delivered via fax, modem, on-line computer searching, telephone, person-to-person interaction via phone, fax, modem, mail):

$\begin{array}{lllll}\text { No VaTue } & 2 & 3 & 4 & 5 \\ & & & & \text { Very Valuable }\end{array}$

20. The value of only traditional library services (1 ibrary services delivered via a physical building or location and face-to-face, personal interaction, the books, journals and periodicals on the shelf, ability to personally select materiais):
1
2
3
4
5

No Value

Very Valuable

21. The value of both services above, electronic and traditional, combined:

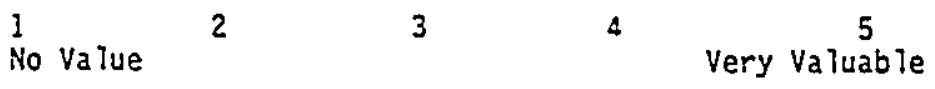

22. Do you have additional coments about electronic and traditional library services?

Thank you for your time! Please return the completed survey to your instructor. 
OWluion of Lbrary \& Intormation Sclence - One Washington Squafe - San Jose. Calitorna 95:92-0029 • scers24-2490

\section{Dear Eaculty Member:}

I am a graduate student enrolled in the Library and Information Science program at San Jose State University, Fullerton Camplis and have elected to write a thesis to complete my studies.

My thesis explores the perceived value and purpose of the traditional ibrary as electronic sources to information, and access to these sources, become available outside the traditional library. The iniversity of Phoenix and University of La verne take advantage of these advances to offer technologicallyenhanced electronic library sezvices to their stucents and have agreed to participate in this study.

To gather the information, a sample of stucents anc all faculty members in the business programs of both universities will be surveyed. It is anticipated that none of the questions on this survey have the potential to cause harm or discomfort to participants. Nor will the study have a direct benefit or risk to any of the participants. The results of this stucy may be oublished, but any information that could result in the identification of participants will remain confidential.

you should understand that the participation of students is voluntary and that choosing not to participate in this study, or in any part of this study, will not affect your relations with the University of La Verne, the University of Phoenix or San Jose State University.

Could you please take a few minutes to complete the attached iaculty survey and return it? I have enclosed a self-addressed, stamped envelope.

If you have questions about this study, I will be happy to talk with you. I can be reached at (714) 649-3092. If you save questions of complaints about research subjects' rights, or in the event of a research related injury, please contact Serena Stanford, Ph.D., Associate Academic Vice President of Gracuate Studies and Research at (408) 924-2480.

sincerely,

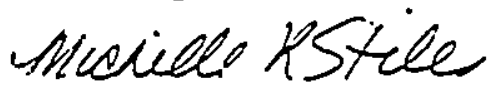

Michelle R. Stiles 


\section{FACUITY IIBRARY SERUICES SURVEY}

1. How well informed do you feel you are of the library services (offCampus Librazy Services) provided by the University of ia verne (LiV)? (circle one)

No Idea what It Is ${ }^{2}$ Unsure ${ }^{3}$ Know $A^{5}$ il About It

?. How did you learn about off-Campus Librazy Services? (check all applicabie)

orientation information

flyers/handouts

ULV staff

personal research librarian presentation

other instructors

other students

wasn't informed of service

3. How would you describe off-Campus Iibrazy Services' services? (check one)

traditional library services--books, periodicais, reference services, databases, personal assistance

electronic library services--fax, computer, modem, on-line searching, telephone

traditiona $i$ and electronic library services

other

4. How often do you use off-Campus Librazy Sezvices? (check one)

1. Do not use

2. Tried one time, won't use aga in

3. Use occasionally, depends on class

4. Use reguiarly for most classes

5. Use for every class

5. Does the information you receive from off-Campus Library Services satisfy youz information need? (check one)

1. No, could not use any of the information provided

2. No, could not use most of the information provided

3. Used some--didn't use some

4. Yes, can use most of the information provided

5. Yes, can consistently use all of the information provided

6. Not applicable, don't use service

6. What is final form (i.e. listing, article, book) you usually get from off-Campus Library Services? (check one)

book

journa l/periodical article

jisting of references and article summaries

listing of references

other

Not applicable, don't use service 
7. Does the final form of the information, as indicated in the previous question, provided by off-Campus ibrary Services meet your needs? (check one)

1. No, I can never use the information in the form provided. I must do a total new search on my own.

2. No, I usualiy can't use the information in the form provided. I use the information to find the suitable form on my own.

3. I use the information in the form as it is provided and search for another form equal number of times.

4. I usually use the information in the form provided. Very seldon do I search for the information on my own.

5. I consistentiy use the information in the form provided by Off-Campus Library Services.

6. Not applicabie, I don't use service.

8. Do you encourage students to use off-Campus Iibrary Sezvices? (check one)

1. No, never

2. A few students

3. A few classes

4. Most students and classes

5. Alt of my students and classes

9. Do you encourage students to use other libraries? (check one)

1. No, never

2. A few students

3. A few classes

4. Most students and classes

5. All of my students and classes

10. Do you use Iibraries other than the servis of off-Campus Library Services? (check one)

1. Yes, I only use other libraries

2. Yes, I regulariy use other libraries

3. I use other libraries and off-Campus Library Services equally

4. I occasionally use other libraries

5. No, i only use off-Campus Library Services

11. If you use Iibrazies other than off-Campus Library Services, what type of Iibrary do you use most often? (check one)

University/College

Comunity College

Public

Special (Law, Medical, etc.)

Electronic

other

Does Not Apply 
12. In the past six months, how often have you used a library other than off-Campus Library Services? (check one)

Not at ail

Once

Twice

Three Times

Four times

Five times

Six times or more

13. If you use Iibraries other than off-Campus Iibrary Services, what is the reason? (check as many as apply)

Would rather do my own research

Materials provided by Off-Campus Library Services are not what is needed

Need to supplement materials provided by Off-Campus Library Services

More convenient to use other library

off-Campus Library Services takes too long to supply information

Want to taik to a person face-to-face to request information

Need actual materials instead of copies of articles

Material provided by Off-Campus Library Services not current enuugh

Material provided by Off-Campus Library Services not historical

Like to browse a collection

Like to do my own electronic searches

Want to do an extensive search of all types of materia?

Unsure how to use the service

Does not apply, I only use Off-Campus Library Services.

14. Off-Camplis Library Sezvices is an electronic based sezvice supported by traditional library services. If you were to compare electronic library services with traditional Iibrary services, please wark the comment(s) that most closely zeflect how you feel. (check as many as apply)

Electronic services make it easier for users to access information than traditional services.

Electronic services enable users to access more information than traditional services.

I fee i comfortable using electronic services.

I would rather use electronic services than the traditional library.

I feel more comfortable asking for help with electronic services than with traditional library services.

Traditional Tibrary services offer greater varieties of information than eiectronic services.

Traditional libraries provide access to more information than just electronic services.

I feel comfortable using a traditional library.

I feel comfortable asking for help in a traditional library.

I can $f$ ind what I want most of the time in a traditional library.

I would rather use a traditional library than electronic services.

other 
15. Please mark the services you understand that off-Campus Iibzary Services currently provide, any service you think it should provide and services you would expect to find at a traditional academic library - a California state university Librazy, soz example. (check as many as apply in each column)

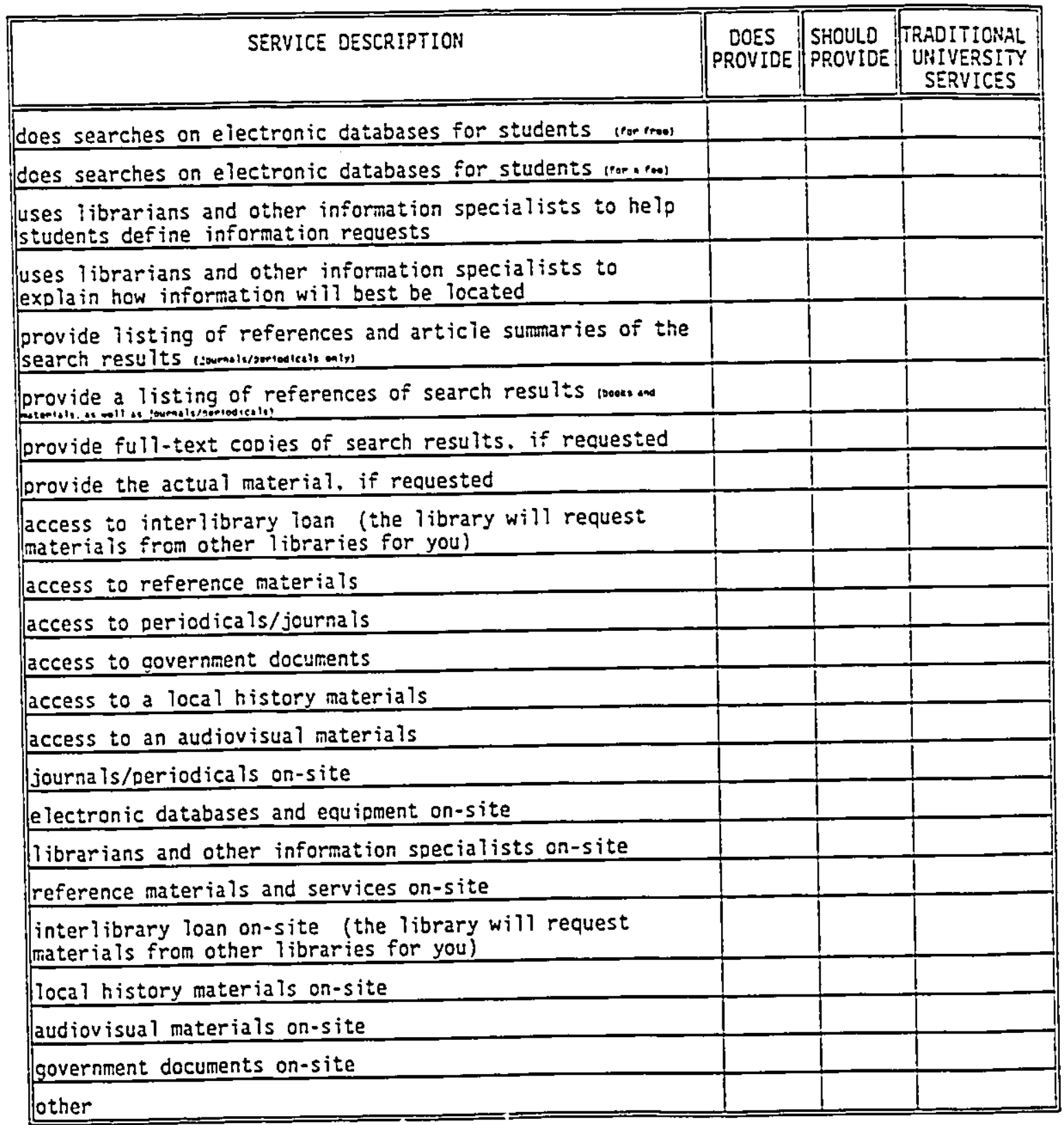


Please circle the number which most closely refiects your feelings about:

16. The value of oniy electronic library services (library services delivered via fax, modem, on-line computer searching, telephone, person-to-person interaction via phone, fax, modem, mail):

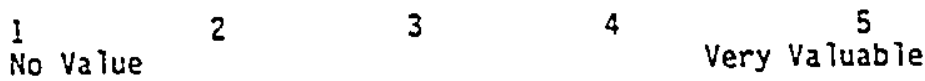

17. The value of only traditionai library services (library services delivered via a physical building or location and face-to-face, personal interaction, the books, journals and periodicals on the sheif, ability to personally select materiais):

INo value $\begin{array}{lllll} & 2 & 3 & 4 & \text { very valuable }\end{array}$

18. The value of both services above, electronic and traditional, combined:

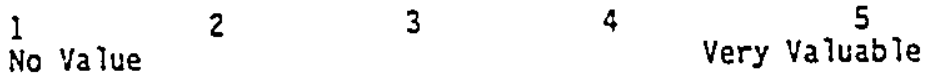

19. Do you have additional comments about electronic and traditional library services?

Thank you for your time! Please return the completed survey in the enclosed envelope. University of La Verne Program you usually teach for: 


\section{Appendix B \\ Universitv of Phoenix Survey Instruments}

\section{TSANJOSE STATE

Dear University of Phoenix Student:

I an a graduate student enfolled in the Librazy and Information Science program at San Jose State University, Eullezton Campus and have elected to write a thesis to complete ny studies.

My thesis explores the perceived value and purpose of the traditional library as electronic sources to information, and access to these sources, become available outside the traditional library. The University of Phoenix and University of Ia verne take advantage of these advances to offer technologicallyenhanced electronic library services to their students and have agreed to participate in this study.

To gather the information, a sample of students in the business programs of both universities will be surveyed. It is anticipated that none of the questions on this survey have the potential to cause ham or discomfort to participants. Nor will the study have a dizect benefit or risk to any of the participants. The zesults of this study may be published, but any information that could result in the identification of participants will remain confidential.

Your class has been selected as part of the sample. You should understand that the participation of students is voluntary and that choosing not to participate in this study, or in any part of this study, will not affect your relations with the Univezsity of Ia Verne, the University of Phoenix or San Jose State University.

Could you please take a few minutes to complete the attached survey? The survey should be returned to your instzuctor when you have finished.

If you have questions about this study, I will be happy to talk with you. I can be reached at (714) 649-3092. If you have questions of complaints about research subjects" rights, or in the event of a research related injuzy, please contact serena Stanford, Ph.D., Associate Academic Vice President of Graduate Studies and Research at (408) 924-2480.

Sincerely, muciele, RStick.

Michelle R. Stiles 


\section{IIBRARY SERVICES SURVEY}

1. What degree are you pursuing at the University of Fhoenix?

2. Do you attend classes in a Learning Center? Yes No

3. How many classes have you completed at the University of phoenix?

4. How well informed do you Seel you are of the librazy services (Iearning Resource Services/Academic Information Services [Zis/AIS]) provided by the University of Phoenix (UOP)? (circle one)

No Idea what it is ${ }^{2} \quad 3 \quad$ Unsure 4 know All About It

5. Fow did you learn about LRS/AIS? (check all applicable)

orientation information

flyers/handouts

vop staff

personal research

librarian presentation instructors other students

wasn't informed of service

6. How would you describe LRS/AIS sezvices? (check one)

traditional library services--books, periodicals, reference services, databases. personal assistance

electronic library services--fax, computer, moden, on-line searching, telephone traditional and electronic ibrary services other

7. How ozten do you use IRS/AIS? (check one)

1. Do not use

2. Tried one time, won't use again

3. Use occasionaliy, depends on class

4. Use reguiarly for most classes

5. Use for every class

8. Does the infomation you receive fzom LRS/AIS satisfy your information need? (check one)

1. No, could not use any of the information provided

2. No, could not use most of the information provided

3. Used some--didn't use some

4. Yes, can use most of the information provided

5. Yes, can consistently use all of the information provided

6. Not applicable, don't use service

9. What is final form (i.e. listing, article, book) you usually get from LRS/AIS? (check one)

book

journal/periodical article

listing of references and article summaries

listing of references

other

Not applicable, don't use service 
10. Does the final sozm of the inforation, as indicated in the previols question, provided by LRS/AIs meet your needs? (check one)

1. No, I can never use the information in the form provided. I nust do a total new search on my own.

2. No, I usually can't use the information in the form provided. I use the information to find the suitable form on my own.

3. I use the infurmation in the form as it is provided and search for another form equa 1 number of times.

4. I usually use the information in the form provided. Very seldon co I search for the information on my own.

the infonsistently use the information in the form provided by LRS/AIS.

6 . Not applicable, I don't use service.

11. Do yop instructors encourage you to use LRS/AIS? (check one)

1. No, never

2. A few of my instructors have

3. Some have, some haven't .- its equa i

4. Most of my instructors have

5. All of my instructors have

12. Do UOP instructors encourage you to use othez librazies? (check one)

1. No, never

2. A few of my instructors have

3. Some have, some haven't ..- its equal

4. Most of my instructors have

5. All of my instruetors have

13. Do you use libzaries other than the services of LRS/AIS? (check one)

1. Yes, I only use other libraries

2. Yes, I reguiarly use other libraries

3. I use other Tibraries and LRS/AIS equaily

4. I occasionaliy use other libraries

5. No, I only use LRS/AIS

14. If you use Iibraries other than LRS/AIS, what type of library do you use most often? (check one)

University/Coilege

Comunity College

Public

Special (Law, Medicai, etc.)

Electronic

other

Does Not Apply

15. In the past six months, how often have you used a librazy other than IRS/AIS? (check one)

Not at all

Once

Twice

Three Times

Four times

Five times

Six times or more 
16. If you use iibraries other than IRS/AIS, what is the reason? (check as many as apply)

Would rather do my own research

Materials provided by LRS/AIS are not what is needed

Need to supplement materials provided by LRS/AiS

More convenient to use other library

LRS/AIS takes :oo long to supply information

Hant to talk to a person face-to-face to request information

Need actual materials instead of copies of articles

Materiai provided by LRS/AIS not current enough

Material provided by LRS/AIS not historical

Like to browse a collection

Like to do my own electronic searches

Hant to do an extensive search of all types of materiai

Unsure how to use the service

Does not appiy, I on?y use LRS/AIS.

17. IRS/AIS is an electronic based service. If you were to compaze electronic librazy services with tradicional library sezvices, please matk the coment(s) that most closely zetlect how you feel. (check as many as apply)

Eiectronic services make it easier for users to access information than traditional services.

Electronic services enable users to access more information than traditional services. I feei confortable using eiectronic services.

I would rather use electronic services than the traditional library.

feel more comfortable asking for help with electronic services than with traditional library services.

iraditional library services offer greater variet as of information than electrcnic services.

Traditional libraries provide access to more information than just eiectronic services.

I feel comfortabie using a traditional library.

I feel comfortable asking for help in a traditiona i library.

I can find what I want most of the time in a traditionai library. i would rather use a traditional library than electronic services. other 
18. Please mazk the services you uncerstand that LRS/AIS curzently provide, any service you think it should provide and services you would expect to find at a traditional acadenic Iibrary - a California state University Library, sor example. (check as many as apply in each coluwn)

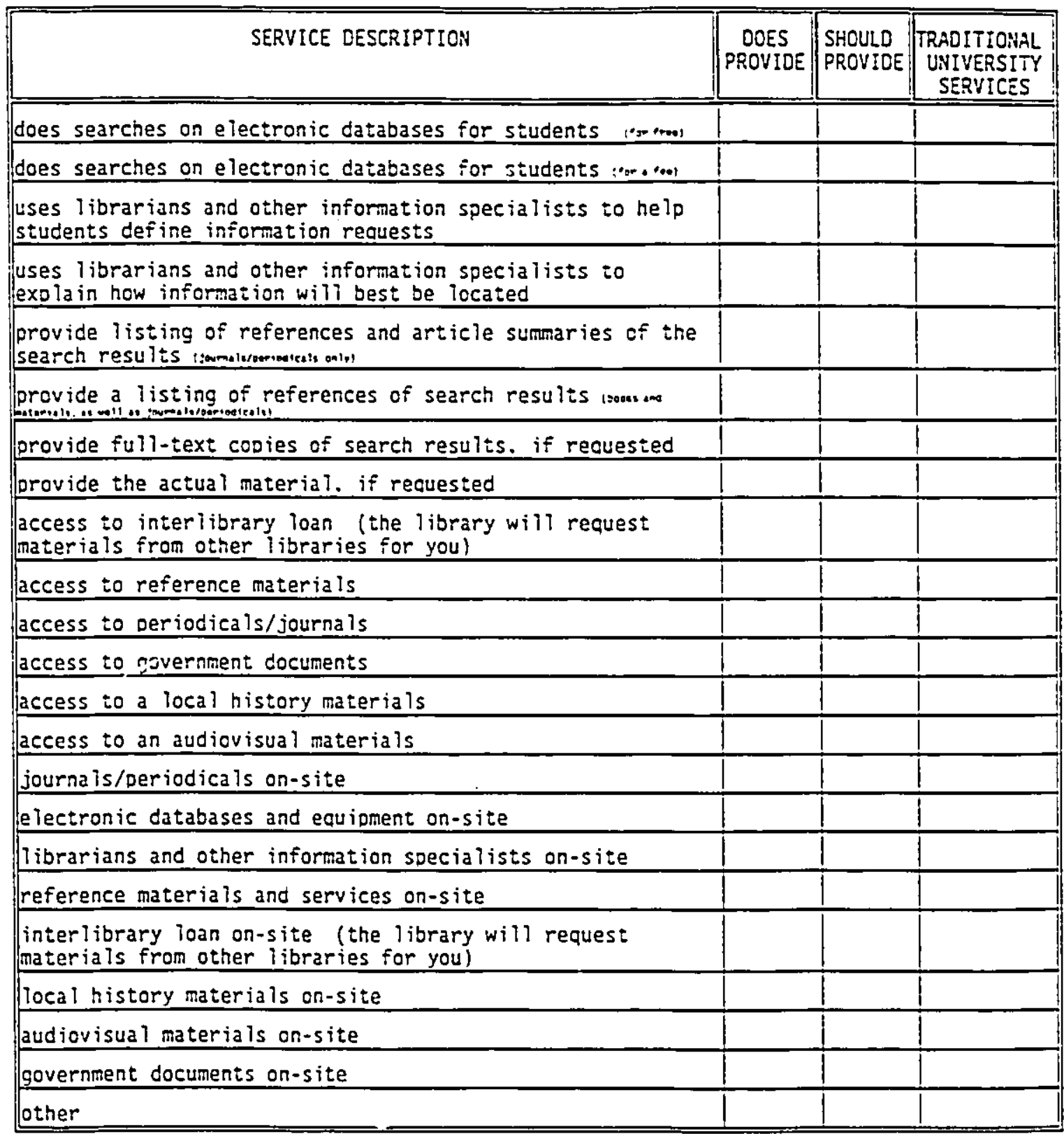


Please circle the number which most closely reflects your feelings about:

19. The value of only electronic library services (library services delivered via fax, modem, on-line computer searching, telephone, person-to-person interaction via phone, fax, modem, mail):

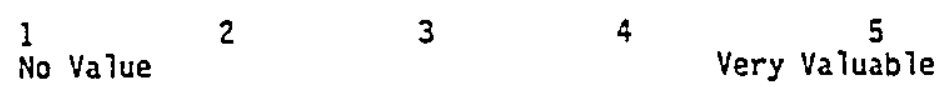

20. The value of only traditional library services (library services delivered via a physical building or location and face-to-face, personal interaction, the books, journa is and periodicais on the sheif, ability to personaliy select materials):

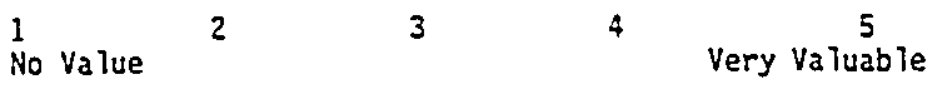

21. The value of both services above, electronic and traditional, combined:

$\begin{array}{lllll}\text { No value } & 2 & 3 & 4 & \text { Very valuable }\end{array}$

22. Do you have additional comments about electronic and traditional ibrary services? 
Owlston of Lbray \& Information Selence - One Washington Squaro - San Jose. Catifornia 95192-0029 - $400 / 924-2490$

\section{Dear Eaculty Member:}

I am a graduate student enrolled in the Library and Information Science program at San Jose State University, Fullerton Campus and have elected to write a thesis to complete my studies.

By thesis explores the perceived value and purpose of the traditional Iibrary as electronic sources to information, and access to these sources, become available outside the traititional library. The University of Phoenix and University of La Verne take advantage of these advances to offer technologicallyenhanced electronic library services to their students and have agreed to participate in this study.

To gather the information, a sample of students and all faculty nembers in the business programs of both universities will be surveyed. It is anticipated that none of the questions on this survey have the potential to cause harm or discomfort to participants. Nor will the study have a direct benefit or risk to any of the participants. The results of this study may be published, but any information that could result in the identification of participants will remain conficential.

You should understand that the participation of students is voluntary and that choosing not to participate in this study, or in any part of this study, will not affect your relations with the University of La Verne, the University of Phoenix or San Jose State Univẹsity.

Could you please take a few minutes to complete the attached faculty survey and return it? I have enclosed a self-addressed, stamped envelope.

If you have questions about this study, I will be happy to talk with you. I can be reached at (714) 649-3092. If you have questions of complaints about research subjects' rights, or in the event of a research related injury, please contact Serena stanford, Ph.D., Associate Academic Vice President of Graduate Studies and Research at (408) 924-2480.

sincerely,

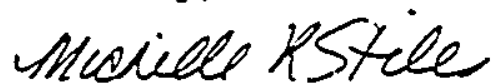

Michelle R. Stiles 


\section{FACUITY IIPRARX SERVICES SUTRVEY}

1. How well informed co you feel you are of the library services (Learning Resource Services/Acadenic Information Services [iRS/AIS]) pzovided by the iniversity of phoenix (COOP)? (circle one)

No Idea what It Is ${ }^{2}$ Unsure 4 know Ali About It

2. Low did you learn about LRS/AIS? (check all applicable)

$\begin{array}{ll}\text { orientation information } & \text { librarian presentation } \\ \text { ilyers/handouts } & \text { Other instructors } \\ \text { UOP staff } & \text { Other students } \\ \text { personal research } & \text { Wasn't informed of service }\end{array}$

3. How would you describe LRS/AIS services? (check one)

traditional i ibrary services--books, periodicals, reference services, databases, persona i assistance electronic library services--fax, computer, modem, on-line searching, telephone traditional and electronic library services other

4. How often do you lise IRS/AIS? (check one)

1. Do not use

2. Tried one time, won't use aga in

3. Use occasionally, depends on class

4. Use regularly for most classes

5. Use for every ciass

5. Does the information you receive fron IRS/AIS satisfy your information need? (check one)

$-$

1. No, could not use any of the information provided

2. No, could not use most of the information provided

3. Used some--didn't use some

4. Yes, can use most of the information provided

5. Yes, can consistently use all of the information provided

6. Not applicable, don't use service

6. What is final form (i.e. listing, article, book) you usually get from LRS/AIS? (check one)

book

journal/periodical article

listing of references and article summaries

listing of references

other

Not applicable, don't use service 
7. Does the final form of the information, as indicated in the previous guestion, provided by IRS/AIS neet your needs? (check one)

1. No, I can never use the information in the form provided. I must do a total new search on my own.

2. No, I usually can't use the information in the form provided. I use the information to find the suitable form on my own.

3. I use the information in the form as it is provided and search for another form equal number of times.

4. I usually use the information in the form provided. Very seldom do I search for the information on my own.

5. I consistently use the information in the form provided by LRS/AIS.

6. Not applicable, I don't use service.

8. Do you encourage students to use IRS/AIS?

(check one)

1. No, never

2. A few students

3. A few classes

4. Most students and classes

5. All of my students and classes

9. Do you encourage stucents to use other libraries? (check one)

1. No, never

2. A few students

3. A few classes

4. Most students and classes

5. All of my students and classes

10. Do you use libraries other than the services of IRS/AIS? (check one)

1. Yes, I only use other libraries

2. Yes, I regularly use other iibraries

3. I Use other libraries and LRS/AIS equally

4. I occasionaliy use other libraries

5. No, I only use LRS/AIS

11. If you use Iibraries other than LRS/AIS, what type of Iibrary do you use most often? (check one)

_University/College __ Community College __ Public

Special (Law, Medical, etc.)

Electronic

other

Does Not Apply

12. In the past six months, how often have you used a librazy other than LRS/AIS? (check one)

Not at all

Once

Twice

Three Times

Four times

Five times

Six times or more 
13. If you use Iibraries other than IRS/AIS, what is the reason? (check as many as appiy)

Hould rather do my own research

Materials provided by LRS/AIS are not what is needed

Need to supplement materials provided by LRS/AIS

More convenient to use other library

LRS/AIS takes too long to supply information

Want to talk to a person face-to-face to request informatian

Need actual materials instead of copies of articles

Material provided by LRS/AIS not current enough

Yaterial provided by LRS/AIS not historica?

bike to browse a collection

Like to do my own electronic searches

want to do an extensive search of all types of materiai

Unsure how to use the service

Does not apply, I only use LRS/AIS.

14. IRS/AIS is an electronic based service. If you were to compare electzonic librazy sezvices with traditional librazy services, please mark the comment(s) that most closely reflect how you feel. (check as many as appiy)

Electronic services make it easier for users to access information than traditional services.

Ejectronic services enabie users to access more information than traditional services. i feel comfortable using electronic services.

I would rather use electronic services than the traditional library.

feel more comfortable asking for help with electronic services than with traditional Tibrary services.

Traditional library services offer greater varieties of information than electronic services.

Traditional libraries provide access to more information than just electronic services.

I feel comfortable using a traditional library.

i feel comfortable asking for thelp in a traditional library.

I can find what I want most of the time in a traditional ibrary.

I would rather use a traditional library than electronic services.

other 
15. Please mark the services you unders=and that LRS/AIS cuzzently provide, any service you think it should provide and services you would expect to Eind at a traditional academic ibrary - a california state University Iibrary, for example. (check as many as apply in each column)

\begin{tabular}{|c|c|c|c|}
\hline SERVICE DESCRIPTION & $\begin{array}{c}\text { DOES } \\
\text { PROVIDE }\end{array}$ & $\begin{array}{l}\text { SHOULD } \\
\text { PROVIDE }\end{array}$ & $\begin{array}{l}\text { TRADITIONAL } \\
\text { UNIVERSITY } \\
\text { SERVICES }\end{array}$ \\
\hline does searches on electronic databases for students (rom mou & & & \\
\hline does searches on electronic databases for students $(\because \ldots \ldots)$ & & & \\
\hline $\begin{array}{l}\text { Uses librarians and other information specialists to help } \\
\text { students define information requests }\end{array}$ & & & \\
\hline $\begin{array}{l}\text { Uses librarians and other information specialists to } \\
\text { exola in how information will best be located }\end{array}$ & & & \\
\hline 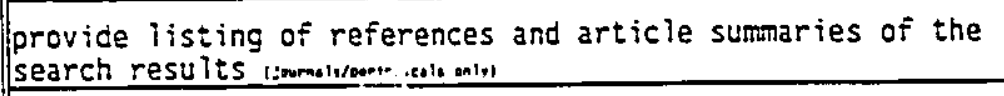 & & & \\
\hline provide a listing of references of search results ban and & & & \\
\hline provide full-text cooies of search results. if requested & & & \\
\hline provide the actual material, if requested & & & \\
\hline $\begin{array}{l}\text { access to interibrary ioan (the library will request } \\
\text { materia is from other libraries for you) }\end{array}$ & & & \\
\hline access to reference macerials & & & \\
\hline access to periodicals/journa is & & & \\
\hline access to government documents & & & \\
\hline access to a local history materials & & & \\
\hline access to an audiovisual materials & & & \\
\hline journais/periodicals on-site & & & \\
\hline electronic databases and equipment on-site & & & \\
\hline Tibrarians and other information specialists on-site & & & \\
\hline reference materials and services on-site & & & \\
\hline $\begin{array}{l}\text { interlibrary loan on-site (the ibbrary will request } \\
\text { materials from other libraries for you) }\end{array}$ & & & \\
\hline local history materials on-site & & & \\
\hline audiovisual materials on-site & & & \\
\hline government documents on-rite & & & \\
\hline other & & & \\
\hline
\end{tabular}


Please circle the number which most closely reflects your feelings about:

16. The value of oniy electronic library services (1 ibrary services delivered via fax. modem, on-line computer searching, telephone, person-to-person interaction via phone, Fax, modem, m? il):

$\begin{array}{lllll}\text { No value } & 2 & 3 & 4 & \text { Very valuable }\end{array}$

17. The value of oniy traditional library services (library services delivered via a physical building or location and face-to-face, personal interaction, the books, journals and periodicals on the shelf, ability to personaliy select materiais):

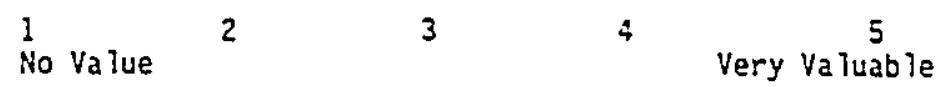

18. The vaive of both services above, electronic and traditional, combined:

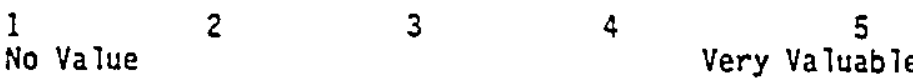

19. Do you have additional comments about electronic and traditional library services?

Thank you for your time! Please return the completed survey in the enclosed envelope.

University of Phoenix Program you usually teach in: 
Appendix $C$

Instructor Explanation Letter

SANJOSE

STATE

Divialon of Lbrary 8 Information Setence - One Washington Square - San Jo5e. Calitornia 95192-0029 - 4C8/924-2490

Dear Instructor:

I an writing a thesis that explores the perceived value and purpose of the traditional library and library services as technology-enhanced services become widely available. The University of Phoenix and University of la verne, who offer technologically-enhanced electronic library sezvices to their students and faculty, have agreed to participate in this study.

To gather the information, a sample of students and all faculty members in the business prograns of both universities will be surveyed. It is anticipated that none of the questions on this survey have the potential to cause harm or discomfort to the particjpants. Nor will the study have a direct benefit or risk to any of the participants. The results of this study may be published, but any information that could result in the identifization of participants will remain confidential.

Your cliss was selected as part of the student sample. you should understand that the participation of students and faculty is voluntary and that choosing not to participate in this study, or in any part of this study, will not affect the participants relations with the University of la verne, the University of Phoenix or San Jose State University.

Please distribute the survey to the students. It should take less than ten minutes to complete. The completed surveys should be returned to the Bookstore in the enclosed envelope and they will send the package to me.

If you have questions about this study, I will be happy to talk with you. I can be reached at (714) 649-3092. If you have questions or complaints about research subjects' rights, or in the event of a research related injury, please contact serena Stanford, Ph.D., Associate Academic Vice President of Graduate Studies and Research at (408) 924-2480.

Thank you very much for the class time and your assistance.

Sincerely,

tmachele r stiles

richelle R. Stiles 
Appendix D

All Grouping Responses to Survey Table on Library Services Table $D-1$

Library Services the offered Service Does Provide

\begin{tabular}{|c|c|c|c|c|c|}
\hline Service Description & $\begin{array}{c}t \\
\text { value }\end{array}$ & $d f$ & $\begin{array}{c}\text { Significant } \\
Y / N\end{array}$ & $\begin{array}{l}\text { ULV } \\
\text { Mean }\end{array}$ & $\begin{array}{l}\text { UoP } \\
\text { Mean }\end{array}$ \\
\hline $\begin{array}{l}\text { does searches on } \\
\text { electronic databases for } \\
\text { students (for free) }\end{array}$ & .3 & 392 & $\mathrm{~N}$ & .76 & .77 \\
\hline $\begin{array}{l}\text { does searches on } \\
\text { electronic databases for } \\
\text { students (for a fee) }\end{array}$ & 1.5 & 391 & $\mathrm{~N}$ & .68 & .44 \\
\hline $\begin{array}{l}\text { uses librarians and other } \\
\text { information specialists } \\
\text { to help students define } \\
\text { information requests }\end{array}$ & $3.0 *$ & 391 & $Y$ & .61 & .46 \\
\hline $\begin{array}{l}\text { uses librarians and other } \\
\text { information specialists } \\
\text { to explain how } \\
\text { information will best be } \\
\text { located }\end{array}$ & $4.0 *$ & 391 & $Y$ & .54 & .34 \\
\hline
\end{tabular}




\begin{tabular}{|c|c|c|c|c|c|}
\hline Service Description & $\begin{array}{c}t \\
\text { value }\end{array}$ & $d f$ & $\underset{Y / N}{\text { Significant }}$ & $\begin{array}{l}\text { ULV } \\
\text { Mean }\end{array}$ & $\begin{array}{l}\text { UOP } \\
\text { Mean }\end{array}$ \\
\hline $\begin{array}{l}\text { provide listing of } \\
\text { references and article } \\
\text { summaries of the search } \\
\text { results } \\
\text { (journals/periodicals } \\
\text { only) }\end{array}$ & .5 & 391 & $\mathrm{~N}$ & .72 & .74 \\
\hline $\begin{array}{l}\text { provide a listing of } \\
\text { references of search } \\
\text { results (books and } \\
\text { materials, as well as } \\
\text { journal/periodicals) }\end{array}$ & .4 & 391 & $\mathbf{N}$ & .71 & .68 \\
\hline $\begin{array}{l}\text { provide full-text copies } \\
\text { of search results if } \\
\text { requested }\end{array}$ & .3 & 391 & $x$ & .54 & .53 \\
\hline $\begin{array}{l}\text { provide actual material, } \\
\text { if requested }\end{array}$ & $3.7 *$ & 391 & $\mathbf{Y}$ & .40 & .23 \\
\hline $\begin{array}{l}\text { access to interlibrary } \\
\text { loan (the Iibrary will } \\
\text { request materials from } \\
\text { other libraries for you) }\end{array}$ & $6.2 \star$ & 391 & $\mathbf{Y}$ & .44 & .16 \\
\hline
\end{tabular}


106

\begin{tabular}{|c|c|c|c|c|}
\hline Service Description & $\begin{array}{c}t \\
\text { value }\end{array}$ & $\underset{Y / N}{S_{Y}}$ & $\begin{array}{l}\text { ULV } \\
\text { Mean }\end{array}$ & $\begin{array}{l}\text { UOP } \\
\text { Mean }\end{array}$ \\
\hline $\begin{array}{l}\text { access to reference } \\
\text { materials }\end{array}$ & $5.7 * 391$ & $Y$ & .68 & .39 \\
\hline $\begin{array}{l}\text { access to } \\
\text { periodicals/journals }\end{array}$ & $3.3 * 391$ & $Y$ & .65 & .57 \\
\hline $\begin{array}{l}\text { access to government } \\
\text { documents }\end{array}$ & $2.0 * 391$ & $Y$ & .44 & .34 \\
\hline $\begin{array}{l}\text { access to local history } \\
\text { materials }\end{array}$ & $4.1 * 391$ & $\Psi$ & .43 & .23 \\
\hline $\begin{array}{l}\text { access to audiovisual } \\
\text { materials }\end{array}$ & $4.9 * 391$ & $Y$ & .36 & .16 \\
\hline $\begin{array}{l}\text { journals/periodicals on- } \\
\text { site }\end{array}$ & $6.4 * 391$ & $\mathrm{Y}$ & .45 & .16 \\
\hline $\begin{array}{l}\text { electronic databases and } \\
\text { equipment on-site }\end{array}$ & $4.6 * 391$ & $Y$ & .51 & .28 \\
\hline $\begin{array}{l}\text { librarians and other } \\
\text { information specialists } \\
\text { on-site }\end{array}$ & $5.3 * 390$ & $Y$ & .41 & .17 \\
\hline $\begin{array}{l}\text { reference materials and } \\
\text { services on-site }\end{array}$ & $4.2 * 390$ & $\mathbf{Y}$ & .39 & .16 \\
\hline
\end{tabular}




\begin{tabular}{|c|c|c|c|c|c|}
\hline Service Description & $\begin{array}{c}t \\
\text { value }\end{array}$ & $d f$ & $\begin{array}{c}\underset{Y / N}{S i g n i f i c a n t} \\
\text { S }\end{array}$ & $\begin{array}{l}\text { ULV } \\
\text { Mean }\end{array}$ & $\begin{array}{l}\text { Uop } \\
\text { Mean }\end{array}$ \\
\hline $\begin{array}{l}\text { interlibrary loan on-site } \\
\text { (the library will request } \\
\text { materials from other } \\
\text { libraries for you) }\end{array}$ & $5.9 *$ & 390 & $Y$ & .36 & .12 \\
\hline $\begin{array}{l}\text { local history materials } \\
\text { on-site }\end{array}$ & $6.1 *$ & 389 & $Y$ & .67 & .06 \\
\hline $\begin{array}{l}\text { audiovisual materials on- } \\
\text { site }\end{array}$ & $5.8 *$ & 389 & $Y$ & .29 & .08 \\
\hline $\begin{array}{l}\text { government documents on- } \\
\text { site }\end{array}$ & $3.9 *$ & 389 & $Y$ & .20 & .07 \\
\hline other & .9 & 389 & $\mathbf{N}$ & .05 & .03 \\
\hline
\end{tabular}

*D<<.05, two-tailed 
Table D-2

Iibrary Services the offered service should Provide

\begin{tabular}{|c|c|c|c|c|c|}
\hline Service Description & $\begin{array}{c}t \\
\text { value }\end{array}$ & df & $\begin{array}{c}\text { Significant } \\
Y / N\end{array}$ & $\begin{array}{l}\text { ULV } \\
\text { Mean }\end{array}$ & $\begin{array}{l}\text { UOP } \\
\text { Mean }\end{array}$ \\
\hline $\begin{array}{l}\text { does searches on } \\
\text { electronic databases for } \\
\text { students (for free) }\end{array}$ & 1.8 & 343 & $\mathbf{N}$ & .48 & .38 \\
\hline $\begin{array}{l}\text { does searches on } \\
\text { electronic databases for } \\
\text { students (for a fee) }\end{array}$ & 1.7 & 343 & $\mathrm{~N}$ & .26 & .18 \\
\hline $\begin{array}{l}\text { uses librarians and other } \\
\text { information specialists } \\
\text { to help students define } \\
\text { information requests }\end{array}$ & .6 & 343 & $\mathbf{N}$ & .46 & .43 \\
\hline $\begin{array}{l}\text { uses librarians and other } \\
\text { information specialists } \\
\text { to explain how } \\
\text { information will best be } \\
\text { located }\end{array}$ & .7 & 343 & $\mathrm{~N}$ & .45 & .41 \\
\hline
\end{tabular}


109

\begin{tabular}{|c|c|c|c|c|c|}
\hline Service Description & $\begin{array}{c}\text { t } \\
\text { value }\end{array}$ & df & $\underset{Y / N}{\underset{Y}{\text { Significant }}}$ & $\begin{array}{l}\text { ULV } \\
\text { Mean }\end{array}$ & $\begin{array}{l}\text { Uop } \\
\text { Mean }\end{array}$ \\
\hline $\begin{array}{l}\text { provide listing of } \\
\text { references and article } \\
\text { summaries of the search } \\
\text { results } \\
\text { (journals/periodicals } \\
\text { only) }\end{array}$ & $2.2 *:$ & 343 & $\mathbf{Y}$ & .37 & .24 \\
\hline $\begin{array}{l}\text { provide a listing of } \\
\text { references of search } \\
\text { results (books and } \\
\text { materials, as well as } \\
\text { journal/periodicals) }\end{array}$ & $2.4 *$ & 343 & $\mathrm{Y}$ & .46 & .33 \\
\hline $\begin{array}{l}\text { provide full-text copies } \\
\text { of search results if } \\
\text { requested }\end{array}$ & $2.2 *$ & 343 & $\mathrm{Y}$ & .53 & .41 \\
\hline $\begin{array}{l}\text { provide actual material, } \\
\text { if requested }\end{array}$ & .8 & 343 & $\mathbf{N}$ & .48 & .43 \\
\hline $\begin{array}{l}\text { access to interlibrary } \\
\text { loan (the library will } \\
\text { request materials from } \\
\text { other libraries for you) }\end{array}$ & 2.5 & 343 & $\mathbf{N}$ & .57 & .48 \\
\hline
\end{tabular}


110

\begin{tabular}{|c|c|c|c|c|c|}
\hline Service Description & $\begin{array}{c}t \\
\text { value }\end{array}$ & $d f$ & 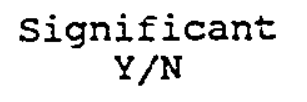 & $\begin{array}{l}\text { ULV } \\
\text { Mean }\end{array}$ & $\begin{array}{l}\text { UOP } \\
\text { Mean }\end{array}$ \\
\hline $\begin{array}{l}\text { access to reference } \\
\text { materials }\end{array}$ & 1.0 & 343 & $\mathrm{~N}$ & .46 & .40 \\
\hline $\begin{array}{l}\text { access to } \\
\text { periodicals/journals }\end{array}$ & 1.1 & 343 & $\mathrm{~N}$ & .45 & .39 \\
\hline $\begin{array}{l}\text { access to government } \\
\text { documents }\end{array}$ & 1.8 & 343 & $\mathrm{~N}$ & .55 & .44 \\
\hline $\begin{array}{l}\text { access to local history } \\
\text { materials }\end{array}$ & $3.3 *$ & 343 & $\mathrm{Y}$ & .56 & .37 \\
\hline $\begin{array}{l}\text { access to audiovisual } \\
\text { materials }\end{array}$ & 1.2 & 343 & $\mathrm{~N}$ & .51 & .44 \\
\hline $\begin{array}{l}\text { journals/periodicals on- } \\
\text { site }\end{array}$ & 1.3 & 343 & $\mathbf{N}$ & .47 & .40 \\
\hline $\begin{array}{l}\text { electronic databases and } \\
\text { equipment on-site }\end{array}$ & .1 & 343 & $\mathrm{~N}$ & .47 & .47 \\
\hline $\begin{array}{l}\text { librarians and other } \\
\text { information specialists } \\
\text { on-site }\end{array}$ & .3 & 343 & $\mathrm{~N}$ & .46 & .44 \\
\hline $\begin{array}{l}\text { reference materials and } \\
\text { services on-site }\end{array}$ & 1.5 & 343 & $\mathrm{~N}$ & .44 & .36 \\
\hline
\end{tabular}


111

\begin{tabular}{|c|c|c|c|c|c|}
\hline Service Description & $\begin{array}{c}t \\
\text { value }\end{array}$ & $d f$ & $\underset{Y / N}{\underset{N}{\text { Significant }}}$ & $\begin{array}{l}\text { ULV } \\
\text { Mean }\end{array}$ & $\begin{array}{l}\text { UOP } \\
\text { Mean }\end{array}$ \\
\hline $\begin{array}{l}\text { interlibrary loan on-site } \\
\text { (the library will request } \\
\text { materials from other } \\
\text { libraries for you) }\end{array}$ & .9 & 343 & $\mathrm{~N}$ & .5 & .45 \\
\hline $\begin{array}{l}\text { local history materials } \\
\text { on-site }\end{array}$ & .8 & 343 & $\mathrm{~N}$ & .42 & .37 \\
\hline $\begin{array}{l}\text { audiovisual materials on- } \\
\text { site }\end{array}$ & .5 & 343 & $\mathbf{N}$ & .4 & .37 \\
\hline $\begin{array}{l}\text { government documents on- } \\
\text { site }\end{array}$ & .1 & 343 & $\mathbf{N}$ & .42 & .36 \\
\hline other & 1.0 & 341 & $\mathbf{N}$ & .12 & .09 \\
\hline
\end{tabular}

*פ<.05, two-tailed 
Table D-3

Library Services A Traditional university Library Provides

\begin{tabular}{|c|c|c|c|c|c|}
\hline Service Description & $\begin{array}{c}t \\
\text { value }\end{array}$ & $d f$ & $\begin{array}{c}\text { Significant } \\
Y / N\end{array}$ & $\begin{array}{l}\text { ULV } \\
\text { Mean }\end{array}$ & $\begin{array}{l}\text { UOP } \\
\text { Mean }\end{array}$ \\
\hline $\begin{array}{l}\text { does searches on } \\
\text { electronic databases for } \\
\text { students (for free) }\end{array}$ & 1.6 & 294 & $\mathrm{~N}$ & .43 & .33 \\
\hline $\begin{array}{l}\text { does searches on } \\
\text { electronic databases for } \\
\text { students (for a fee) }\end{array}$ & .6 & 288 & $\mathbf{N}$ & .25 & .28 \\
\hline $\begin{array}{l}\text { uses librarians and other } \\
\text { information specialists } \\
\text { to help students define } \\
\text { information requests }\end{array}$ & $2.3 *$ & 288 & $\mathbf{Y}$ & .54 & .68 \\
\hline $\begin{array}{l}\text { uses librarians and other } \\
\text { information specialists } \\
\text { to explain how } \\
\text { information will best be } \\
\text { located }\end{array}$ & 1.3 & 292 & $\mathrm{~N}$ & .62 & .69 \\
\hline
\end{tabular}




\begin{tabular}{|c|c|c|c|c|c|}
\hline Service Description & $\begin{array}{c}t \\
\text { value }\end{array}$ & $d f$ & $\begin{array}{c}\underset{Y / N}{\text { Significant }} \\
\text { / }\end{array}$ & $\begin{array}{l}\text { ULV } \\
\text { Mean }\end{array}$ & $\begin{array}{l}\text { UOP } \\
\text { Mean }\end{array}$ \\
\hline $\begin{array}{l}\text { provide listing of } \\
\text { references and article } \\
\text { summaries of the search } \\
\text { results } \\
\text { (journals/periodicals } \\
\text { only) }\end{array}$ & .1 & 292 & $\mathbf{N}$ & .52 & .51 \\
\hline $\begin{array}{l}\text { provide a listing of } \\
\text { references of search } \\
\text { results (books and } \\
\text { materials, as well as } \\
\text { journal/periodicals) }\end{array}$ & .5 & 292 & $\mathbf{N}$ & .53 & .50 \\
\hline $\begin{array}{l}\text { provide full-text copies } \\
\text { of search results if } \\
\text { requested }\end{array}$ & .2 & 292 & $\mathbf{N}$ & .47 & .49 \\
\hline $\begin{array}{l}\text { provide actual material, } \\
\text { if requested }\end{array}$ & .6 & 292 & $\mathbf{N}$ & .54 & .57 \\
\hline $\begin{array}{l}\text { access to interlibrary } \\
\text { loan (the library will } \\
\text { request materials from } \\
\text { other libraries for you) }\end{array}$ & $2.9 *$ & 292 & $Y$ & .46 & .64 \\
\hline
\end{tabular}


114

\begin{tabular}{|c|c|c|c|c|c|}
\hline Service Description & $\begin{array}{c}t \\
\text { value }\end{array}$ & $d f$ & $\underset{Y / N}{\underset{Y}{\text { Significant }}}$ & $\begin{array}{l}\text { ULV } \\
\text { Mean }\end{array}$ & $\begin{array}{l}\text { UOP } \\
\text { Mean }\end{array}$ \\
\hline $\begin{array}{l}\text { access to reference } \\
\text { materials }\end{array}$ & 1.8 & 292 & $\mathrm{~N}$ & .62 & .72 \\
\hline $\begin{array}{l}\text { access to } \\
\text { periodicals/journals }\end{array}$ & $2.2 *$ & 292 & $Y$ & .62 & .74 \\
\hline $\begin{array}{l}\text { access to government } \\
\text { documents }\end{array}$ & $2.2 \star$ & 292 & $Y$ & .58 & .71 \\
\hline $\begin{array}{l}\text { access to local history } \\
\text { materials }\end{array}$ & 1.3 & 292 & $\mathrm{~N}$ & .62 & .70 \\
\hline $\begin{array}{l}\text { access to audiovisual } \\
\text { materials }\end{array}$ & 1.4 & 292 & $\mathrm{~N}$ & .60 & .68 \\
\hline $\begin{array}{l}\text { journals/periodicals on- } \\
\text { site }\end{array}$ & .3 & 292 & $\mathrm{~N}$ & .69 & .71 \\
\hline $\begin{array}{l}\text { electronic databases and } \\
\text { equipment on-site }\end{array}$ & 1.4 & 292 & $\mathrm{~N}$ & .54 & .63 \\
\hline $\begin{array}{l}\text { librarians and other } \\
\text { information specialists } \\
\text { on-site }\end{array}$ & 1.5 & 292 & $\mathrm{~N}$ & .67 & .76 \\
\hline $\begin{array}{l}\text { reference materials and } \\
\text { services on-site }\end{array}$ & 1.9 & 292 & $\mathbf{N}$ & .64 & .76 \\
\hline
\end{tabular}


115

\begin{tabular}{|c|c|c|c|c|c|}
\hline Service Description & $\begin{array}{c}t \\
\text { value }\end{array}$ & df & $\underset{Y / N}{\underset{N}{\text { Significant }}}$ & $\begin{array}{l}\text { UIV } \\
\text { Mean }\end{array}$ & $\begin{array}{l}\text { UOP } \\
\text { Mean }\end{array}$ \\
\hline $\begin{array}{l}\text { interlibrary loan on-site } \\
\text { (the library will request } \\
\text { materials from other } \\
\text { libraries for you) }\end{array}$ & $2.3 *$ & 291 & $Y$ & .54 & .68 \\
\hline $\begin{array}{l}\text { local history materials } \\
\text { on-site }\end{array}$ & $2.2 *$ & 291 & $\mathrm{Y}$ & .57 & .70 \\
\hline $\begin{array}{l}\text { audiovisual materials on- } \\
\text { site }\end{array}$ & $2.8 *$ & 291 & $\mathbf{Y}$ & .55 & .71 \\
\hline $\begin{array}{l}\text { government documents on- } \\
\text { site }\end{array}$ & 1.1 & 291 & $\mathbf{N}$ & .56 & .63 \\
\hline other & .7 & 294 & $\mathrm{~N}$ & .15 & .21 \\
\hline
\end{tabular}


Appendix E

Student Grouping Responses to Survey Table on Library

Services

Tabie E-I

Library Services the offered Service Does Provide

\begin{tabular}{|c|c|c|c|c|c|}
\hline Service Description & $\begin{array}{c}t \\
\text { value }\end{array}$ & $d f$ & $\begin{array}{c}\text { Significant } \\
Y / N\end{array}$ & $\begin{array}{l}\text { ULV } \\
\text { Mean }\end{array}$ & $\begin{array}{l}\text { UOP } \\
\text { Mean }\end{array}$ \\
\hline $\begin{array}{l}\text { does searches on } \\
\text { electronic databases for } \\
\text { students (for free) }\end{array}$ & .4 & 252 & $\mathrm{~N}$ & .78 & .80 \\
\hline $\begin{array}{l}\text { does searches on } \\
\text { electronic databases for } \\
\text { students (for a fee) }\end{array}$ & $2.3 *$ & 252 & $Y$ & .33 & .47 \\
\hline $\begin{array}{l}\text { uses librarians and other } \\
\text { information specialists } \\
\text { to help students define } \\
\text { information requests }\end{array}$ & $3.5 *$ & 252 & $\Psi$ & .64 & .42 \\
\hline $\begin{array}{l}\text { uses Iibrarians and other } \\
\text { information specialists } \\
\text { to explain how } \\
\text { information will best be } \\
\text { located }\end{array}$ & $3.8 *$ & 252 & $Y$ & .54 & .31 \\
\hline
\end{tabular}




\begin{tabular}{|c|c|c|c|c|c|}
\hline Service Description & $\begin{array}{c}t \\
\text { value }\end{array}$ & $d f$ & $\underset{Y / N}{\underset{N}{S i g n i f i c a n t}}$ & $\begin{array}{l}\text { ULV } \\
\text { Mean }\end{array}$ & $\begin{array}{l}\text { UOP } \\
\text { Mean }\end{array}$ \\
\hline $\begin{array}{l}\text { provide listing of } \\
\text { references and article } \\
\text { summaries of the search } \\
\text { results } \\
\text { (journals/periodicals } \\
\text { only) }\end{array}$ & .1 & 252 & $\mathbf{N}$ & .73 & .73 \\
\hline $\begin{array}{l}\text { provide a listing of } \\
\text { references of search } \\
\text { results (books and } \\
\text { materials, as well as } \\
\text { journal/periodicals) }\end{array}$ & 1.0 & 252 & $N$ & .71 & .65 \\
\hline $\begin{array}{l}\text { provide full-text copies } \\
\text { of search results if } \\
\text { requested }\end{array}$ & .7 & 252 & $\mathbf{N}$ & .54 & .50 \\
\hline $\begin{array}{l}\text { provide actual material, } \\
\text { if requested }\end{array}$ & $2.1 *$ & 252 & $Y$ & .37 & .25 \\
\hline $\begin{array}{l}\text { access to interlibrary } \\
\text { loan (the library will } \\
\text { request materials from } \\
\text { other libraries for you) }\end{array}$ & $5.7 *$ & 252 & $Y$ & .43 & .13 \\
\hline
\end{tabular}


118

\begin{tabular}{|c|c|c|c|c|c|}
\hline Service Description & $\begin{array}{c}t \\
\text { value }\end{array}$ & df & $\underset{Y / N}{\underset{Y}{\text { Significant }}}$ & $\begin{array}{l}\text { ULV } \\
\text { Mean }\end{array}$ & $\begin{array}{l}\text { UOP } \\
\text { Mean }\end{array}$ \\
\hline $\begin{array}{l}\text { access to reference } \\
\text { materials }\end{array}$ & $4.7 *$ & 252 & $\mathbf{Y}$ & .64 & .36 \\
\hline $\begin{array}{l}\text { access to } \\
\text { periodicals/journals }\end{array}$ & $3.0 *$ & 252 & $\mathrm{Y}$ & .62 & .43 \\
\hline $\begin{array}{l}\text { access to government } \\
\text { documents }\end{array}$ & 1.5 & 252 & $\mathrm{~N}$ & .40 & .31 \\
\hline $\begin{array}{l}\text { access to local history } \\
\text { materials }\end{array}$ & $3.0 *$ & 252 & $\mathbf{Y}$ & .42 & .24 \\
\hline $\begin{array}{l}\text { access to audiovisual } \\
\text { materials }\end{array}$ & $3.9 *$ & 252 & $Y$ & .38 & .17 \\
\hline $\begin{array}{l}\text { journals/periodicals on- } \\
\text { site }\end{array}$ & $4.6 *$ & 252 & $\Psi$ & .46 & .20 \\
\hline $\begin{array}{l}\text { electronic databases and } \\
\text { equipment on-site }\end{array}$ & $4.5 *$ & 251 & $Y$ & .48 & .22 \\
\hline $\begin{array}{l}\text { librarians and other } \\
\text { information specialists } \\
\text { on-site }\end{array}$ & $4.3 *$ & 251 & $\mathrm{Y}$ & .42 & .18 \\
\hline $\begin{array}{l}\text { reference materials and } \\
\text { services on-site }\end{array}$ & $4.0 *$ & 251 & $Y$ & .41 & .18 \\
\hline
\end{tabular}




\begin{tabular}{|c|c|c|c|c|c|}
\hline Service Description & $\begin{array}{c}t^{t} \\
\text { value }\end{array}$ & $d f$ & $\underset{Y / \mathbb{N}}{\underset{Y}{\text { Significant }}}$ & $\begin{array}{l}\text { ULV } \\
\text { Mean }\end{array}$ & $\begin{array}{l}\text { UOP } \\
\text { Mean }\end{array}$ \\
\hline $\begin{array}{l}\text { interlibrary loan on-site } \\
\text { (the library will request } \\
\text { materials from other } \\
\text { libraries for you) }\end{array}$ & $4.6 *$ & 251 & $Y$ & .35 & .12 \\
\hline $\begin{array}{l}\text { local history materials } \\
\text { on-site }\end{array}$ & $5.0 *$ & 251 & $Y$ & .30 & .07 \\
\hline $\begin{array}{l}\text { audiovisual materials on- } \\
\text { site }\end{array}$ & $5.3 *$ & 251 & $\mathbf{Y}$ & .33 & .08 \\
\hline $\begin{array}{l}\text { government documents on- } \\
\text { site }\end{array}$ & $3.0 *$ & 251 & $Y$ & .24 & .10 \\
\hline other & 1.0 & 251 & $\mathbf{N}$ & .07 & .04 \\
\hline
\end{tabular}

*p<.05, two-tailed 
Table E-2

Library services the offered service should provide

\begin{tabular}{|c|c|c|c|c|c|}
\hline Service Description & $\begin{array}{c}t \\
\text { value }\end{array}$ & $d f$ & $\begin{array}{c}\text { Significant } \\
Y / N\end{array}$ & $\begin{array}{l}\text { ULV } \\
\text { Mean }\end{array}$ & $\begin{array}{l}\text { UOP } \\
\text { Mean }\end{array}$ \\
\hline $\begin{array}{l}\text { does searches on } \\
\text { electronic databases for } \\
\text { students (for free) }\end{array}$ & $2.1 *$ & 223 & $Y$ & .47 & .34 \\
\hline $\begin{array}{l}\text { does searches on } \\
\text { electronic databases for } \\
\text { students (for a fee) }\end{array}$ & .9 & 223 & $\mathrm{~N}$ & .24 & .29 \\
\hline $\begin{array}{l}\text { uses librarians and other } \\
\text { information specialists } \\
\text { to help students define } \\
\text { information requests }\end{array}$ & .6 & 223 & $\mathrm{~N}$ & .46 & .42 \\
\hline $\begin{array}{l}\text { uses librarians and other } \\
\text { information specialists } \\
\text { to explain how } \\
\text { information will best be } \\
\text { located }\end{array}$ & .3 & 223 & $\mathbf{N}$ & .46 & .45 \\
\hline
\end{tabular}


121

\begin{tabular}{|c|c|c|c|c|c|}
\hline Service Description & $\begin{array}{c}t \\
\text { value }\end{array}$ & $d f$ & $\underset{\mathrm{Y} / \mathrm{N}}{\underset{\text { Significant }}{ }}$ & $\begin{array}{l}\text { ULV } \\
\text { Mean }\end{array}$ & $\begin{array}{l}\text { UoP } \\
\text { Mean }\end{array}$ \\
\hline $\begin{array}{l}\text { provide listing of } \\
\text { references and article } \\
\text { summaries of the search } \\
\text { results } \\
\text { (journals/periodicals } \\
\text { only) }\end{array}$ & $2.7 *$ & 223 & $Y$ & .36 & .20 \\
\hline $\begin{array}{l}\text { provide a listing of } \\
\text { references of search } \\
\text { results (books and } \\
\text { materials, as well as } \\
\text { journal/periodicals) }\end{array}$ & $2.6 \star$ & 223 & $Y$ & .45 & .28 \\
\hline $\begin{array}{l}\text { provide full-text copies } \\
\text { of search results if } \\
\text { requested }\end{array}$ & $2.8 *$ & 223 & $Y$ & .53 & .35 \\
\hline $\begin{array}{l}\text { provide actual material, } \\
\text { if requested }\end{array}$ & .5 & 223 & $\mathrm{~N}$ & .51 & .47 \\
\hline $\begin{array}{l}\text { access to interlibrary } \\
\text { loan (the library will } \\
\text { request materials from } \\
\text { other libraries for you) }\end{array}$ & 1.1 & 223 & $\mathrm{~N}$ & .58 & .51 \\
\hline
\end{tabular}


122

\begin{tabular}{|c|c|c|c|c|c|}
\hline Service Description & $\begin{array}{c}t \\
\text { value }\end{array}$ & df & $\underset{Y / N}{\text { Significant }_{Y / N}}$ & $\begin{array}{l}\text { ULV } \\
\text { Mean }\end{array}$ & $\begin{array}{l}\text { UOP } \\
\text { Mean }\end{array}$ \\
\hline $\begin{array}{l}\text { access to reference } \\
\text { materials }\end{array}$ & .8 & 223 & $\mathrm{~N}$ & .45 & .40 \\
\hline $\begin{array}{l}\text { access to } \\
\text { periodicals/journals }\end{array}$ & .7 & 223 & $\mathrm{~N}$ & .43 & .38 \\
\hline $\begin{array}{l}\text { access to government } \\
\text { documents }\end{array}$ & 1.3 & 223 & $\mathrm{~N}$ & .54 & .45 \\
\hline $\begin{array}{l}\text { access to local history } \\
\text { materials }\end{array}$ & 1.8 & 223 & $\mathrm{~N}$ & .56 & .44 \\
\hline $\begin{array}{l}\text { access to audiovisual } \\
\text { materials }\end{array}$ & .7 & 223 & $\mathrm{~N}$ & .53 & .48 \\
\hline $\begin{array}{l}\text { journals/periodicals on- } \\
\text { site }\end{array}$ & .3 & 223 & $\mathbf{N}$ & .47 & .45 \\
\hline $\begin{array}{l}\text { electronic databases and } \\
\text { equipment on-site }\end{array}$ & .1 & 233 & $N$ & .49 & .50 \\
\hline $\begin{array}{l}\text { librarians and other } \\
\text { information specialists } \\
\text { on-site }\end{array}$ & 1.5 & 223 & $\mathbf{N}$ & .51 & .41 \\
\hline $\begin{array}{l}\text { reference materials and } \\
\text { services on-site }\end{array}$ & 1.7 & 223 & $\mathrm{~N}$ & .49 & .38 \\
\hline
\end{tabular}


123

\begin{tabular}{|c|c|c|c|c|c|}
\hline Service Description & $\begin{array}{c}t \\
\text { value }\end{array}$ & $d f$ & $\underset{Y / N}{\underset{Y}{\text { Significant }}}$ & $\begin{array}{l}\text { ULV } \\
\text { Mean }\end{array}$ & $\begin{array}{l}\text { UOP } \\
\text { Mean }\end{array}$ \\
\hline $\begin{array}{l}\text { interlibrary loan on-site } \\
\text { (the library will request } \\
\text { materials from other } \\
\text { libraries for you) }\end{array}$ & 1.1 & 223 & $\mathrm{~N}$ & .58 & .51 \\
\hline $\begin{array}{l}\text { Iocal history materials } \\
\text { on-site }\end{array}$ & .1 & 223 & $\mathbf{N}$ & .48 & .48 \\
\hline $\begin{array}{l}\text { audiovisual materials on- } \\
\text { site }\end{array}$ & .1 & 223 & $\mathbf{N}$ & .45 & .45 \\
\hline $\begin{array}{l}\text { government documents on- } \\
\text { site }\end{array}$ & .6 & 223 & $N$ & .46 & .42 \\
\hline other & 1.2 & 223 & $\mathrm{~N}$ & .12 & .12 \\
\hline
\end{tabular}

*פ<.05, two-tailed 
Table E-3

Library Services A Traditional University Library Provides

\begin{tabular}{|c|c|c|c|c|c|}
\hline Service Description & $\begin{array}{c}t \\
\text { Value }\end{array}$ & $d f$ & $\begin{array}{c}\text { Significant } \\
Y / N\end{array}$ & $\begin{array}{l}\text { ULV } \\
\text { Mean }\end{array}$ & $\begin{array}{l}\text { UOP } \\
\text { Mean }\end{array}$ \\
\hline $\begin{array}{l}\text { does searches on } \\
\text { electronic databases for } \\
\text { students (for free) }\end{array}$ & $2.3 *$ & 170 & $Y$ & .44 & .27 \\
\hline $\begin{array}{l}\text { does searches on } \\
\text { electronic databases for } \\
\text { students (for a fee) }\end{array}$ & .6 & 166 & $\mathbf{N}$ & .21 & .25 \\
\hline $\begin{array}{l}\text { uses librarians and other } \\
\text { information specialists } \\
\text { to help students define } \\
\text { information requests }\end{array}$ & 1.8 & 166 & $\mathbf{N}$ & .49 & .63 \\
\hline $\begin{array}{l}\text { uses librarians and other } \\
\text { information specialists } \\
\text { to explain how } \\
\text { information will best be } \\
\text { located }\end{array}$ & 1.0 & 170 & $\mathrm{~N}$ & .61 & .68 \\
\hline
\end{tabular}




\begin{tabular}{|c|c|c|c|c|c|}
\hline Service Description & $\begin{array}{c}t \\
\text { value }\end{array}$ & $d f$ & $\begin{array}{c}\text { Significant } \\
Y / N\end{array}$ & $\begin{array}{l}\text { ULV } \\
\text { Mean }\end{array}$ & $\begin{array}{l}\text { UOP } \\
\text { Mean }\end{array}$ \\
\hline $\begin{array}{l}\text { provide listing of } \\
\text { references and article } \\
\text { summaries of the search } \\
\text { results } \\
\text { (journals/periodicals } \\
\text { only) }\end{array}$ & .4 & 170 & $\mathrm{~N}$ & .49 & .52 \\
\hline $\begin{array}{l}\text { provide a listing of } \\
\text { references of search } \\
\text { results (books and } \\
\text { materials, as well as } \\
\text { journal/periodicals) }\end{array}$ & .0 & 170 & $\mathbf{N}$ & .49 & .49 \\
\hline $\begin{array}{l}\text { provide full-text copies } \\
\text { of search results if } \\
\text { requested }\end{array}$ & .2 & 170 & $\mathbf{N}$ & .43 & .45 \\
\hline $\begin{array}{l}\text { provide actual material, } \\
\text { if requested }\end{array}$ & .1 & 170 & $\mathbf{N}$ & .51 & .52 \\
\hline $\begin{array}{l}\text { access to interlibrary } \\
\text { loan (the library will } \\
\text { request materials from } \\
\text { other libraries for you) }\end{array}$ & 1.7 & 170 & $\mathbf{N}$ & .39 & .52 \\
\hline
\end{tabular}




\begin{tabular}{|c|c|c|c|c|c|}
\hline Service Description & $\begin{array}{c}t \\
\text { value }\end{array}$ & $d f$ & $\underset{Y / N}{\underset{Y}{\text { Significant }}}$ & $\begin{array}{l}\text { ULV } \\
\text { Mean }\end{array}$ & $\begin{array}{l}\text { UOP } \\
\text { Mean }\end{array}$ \\
\hline $\begin{array}{l}\text { access to reference } \\
\text { materials }\end{array}$ & 1.3 & 170 & $\mathbf{N}$ & .55 & .65 \\
\hline $\begin{array}{l}\text { access to } \\
\text { periodicals/journals }\end{array}$ & 1.6 & 170 & $\mathbf{N}$ & .55 & .67 \\
\hline $\begin{array}{l}\text { access to government } \\
\text { documents }\end{array}$ & 1.7 & 170 & $\mathrm{~N}$ & .51 & .64 \\
\hline $\begin{array}{l}\text { access to local history } \\
\text { materials }\end{array}$ & .7 & 170 & $\mathbf{N}$ & .61 & .66 \\
\hline $\begin{array}{l}\text { access to audiovisual } \\
\text { materials }\end{array}$ & .8 & 170 & $\mathbf{N}$ & .55 & .61 \\
\hline $\begin{array}{l}\text { journals/periodicals on- } \\
\text { site }\end{array}$ & .6 & 170 & $\mathbf{N}$ & .65 & .60 \\
\hline $\begin{array}{l}\text { electronic databases and } \\
\text { equipment on-site }\end{array}$ & 1.6 & 170 & $\mathrm{~N}$ & .49 & .61 \\
\hline $\begin{array}{l}\text { librarians and other } \\
\text { information specialists } \\
\text { on-site }\end{array}$ & .8 & 170 & $\mathbf{N}$ & .62 & .68 \\
\hline $\begin{array}{l}\text { reference materials and } \\
\text { services on-site }\end{array}$ & 1.1 & 170 & $\mathbf{N}$ & .58 & .68 \\
\hline
\end{tabular}


127

\begin{tabular}{|c|c|c|c|c|c|}
\hline Service Description & $\begin{array}{c}t \\
\text { value }\end{array}$ & $d f$ & $\underset{Y / N}{\underset{Y}{\text { Significant }}}$ & $\begin{array}{l}\text { ULV } \\
\text { Mean }\end{array}$ & $\begin{array}{l}\text { UOP } \\
\text { Mean }\end{array}$ \\
\hline $\begin{array}{l}\text { interlibrary loan on-site } \\
\text { (the library will request } \\
\text { materials from other } \\
\text { libraries for you) }\end{array}$ & 1.3 & 169 & $\mathbf{N}$ & .43 & .54 \\
\hline $\begin{array}{l}\text { local history materials } \\
\text { on-site }\end{array}$ & .9 & 169 & $\mathrm{~N}$ & .54 & .61 \\
\hline $\begin{array}{l}\text { audiovisual materials on- } \\
\text { site }\end{array}$ & 1.2 & 169 & $\mathrm{~N}$ & .51 & .61 \\
\hline $\begin{array}{l}\text { government documents on- } \\
\text { site }\end{array}$ & .4 & 169 & $\mathrm{~N}$ & .54 & .54 \\
\hline other & .1 & 170 & $\mathbf{N}$ & .19 & .15 \\
\hline
\end{tabular}

«p<.05, two-tailed 
Appendix F

Faculty Grouping Responses to Survey Table on Iibrary

Services

Table F-1

Library Services the offered Service Does Provide

\begin{tabular}{|c|c|c|c|c|c|}
\hline Service Description & $\begin{array}{c}t \\
\text { Value }\end{array}$ & $d f$ & $\begin{array}{c}\text { Significant } \\
\underline{v} / \mathrm{N}\end{array}$ & $\begin{array}{l}\text { ULV } \\
\text { Mean }\end{array}$ & $\begin{array}{l}\text { UOP } \\
\text { Mean }\end{array}$ \\
\hline $\begin{array}{l}\text { does searches on } \\
\text { electronic databases for } \\
\text { students (for free) }\end{array}$ & .5 & 137 & $\mathbf{N}$ & .69 & .74 \\
\hline $\begin{array}{l}\text { does searches on } \\
\text { electronic databases for } \\
\text { students (for a fee) }\end{array}$ & 1.0 & 137 & $\mathbf{N}$ & .52 & .41 \\
\hline $\begin{array}{l}\text { uses librarians and other } \\
\text { information specialists } \\
\text { to help students define } \\
\text { information requests }\end{array}$ & .1 & 137 & $\mathrm{~N}$ & .52 & .51 \\
\hline $\begin{array}{l}\text { uses librarians and other } \\
\text { information specialists } \\
\text { to explain how } \\
\text { information will best be } \\
\text { located }\end{array}$ & 1.8 & 137 & $\mathbf{N}$ & .55 & .37 \\
\hline
\end{tabular}




\begin{tabular}{|c|c|c|c|c|c|}
\hline Service Description & $\begin{array}{c}t \\
\text { value }\end{array}$ & $d f$ & $\underset{y / N}{\operatorname{significant}}$ & $\begin{array}{l}\text { ULV } \\
\text { Mean }\end{array}$ & $\begin{array}{l}\text { UOP } \\
\text { Mean }\end{array}$ \\
\hline $\begin{array}{l}\text { provide listing of } \\
\text { references and article } \\
\text { summaries of the search } \\
\text { results } \\
\text { (journals/periodicals } \\
\text { only) }\end{array}$ & .7 & 137 & $\mathrm{~N}$ & .69 & .75 \\
\hline $\begin{array}{l}\text { provide a listing of } \\
\text { references of search } \\
\text { results (books and } \\
\text { materials, as well as } \\
\text { journal/periodicals) }\end{array}$ & .4 & 137 & $\mathrm{~N}$ & .69 & .73 \\
\hline $\begin{array}{l}\text { provide full-text copies } \\
\text { of search results if } \\
\text { requested }\end{array}$ & .2 & 137 & $\mathrm{~N}$ & .55 & .57 \\
\hline $\begin{array}{l}\text { provide actual material, } \\
\text { if requested }\end{array}$ & $3.6 *$ & 137 & $Y$ & .52 & .2 \\
\hline $\begin{array}{l}\text { access to interlibrary } \\
\text { loan (the library will } \\
\text { request materials from } \\
\text { other libraries for you) }\end{array}$ & $3.0 *$ & 137 & $Y$ & .48 & .21 \\
\hline
\end{tabular}




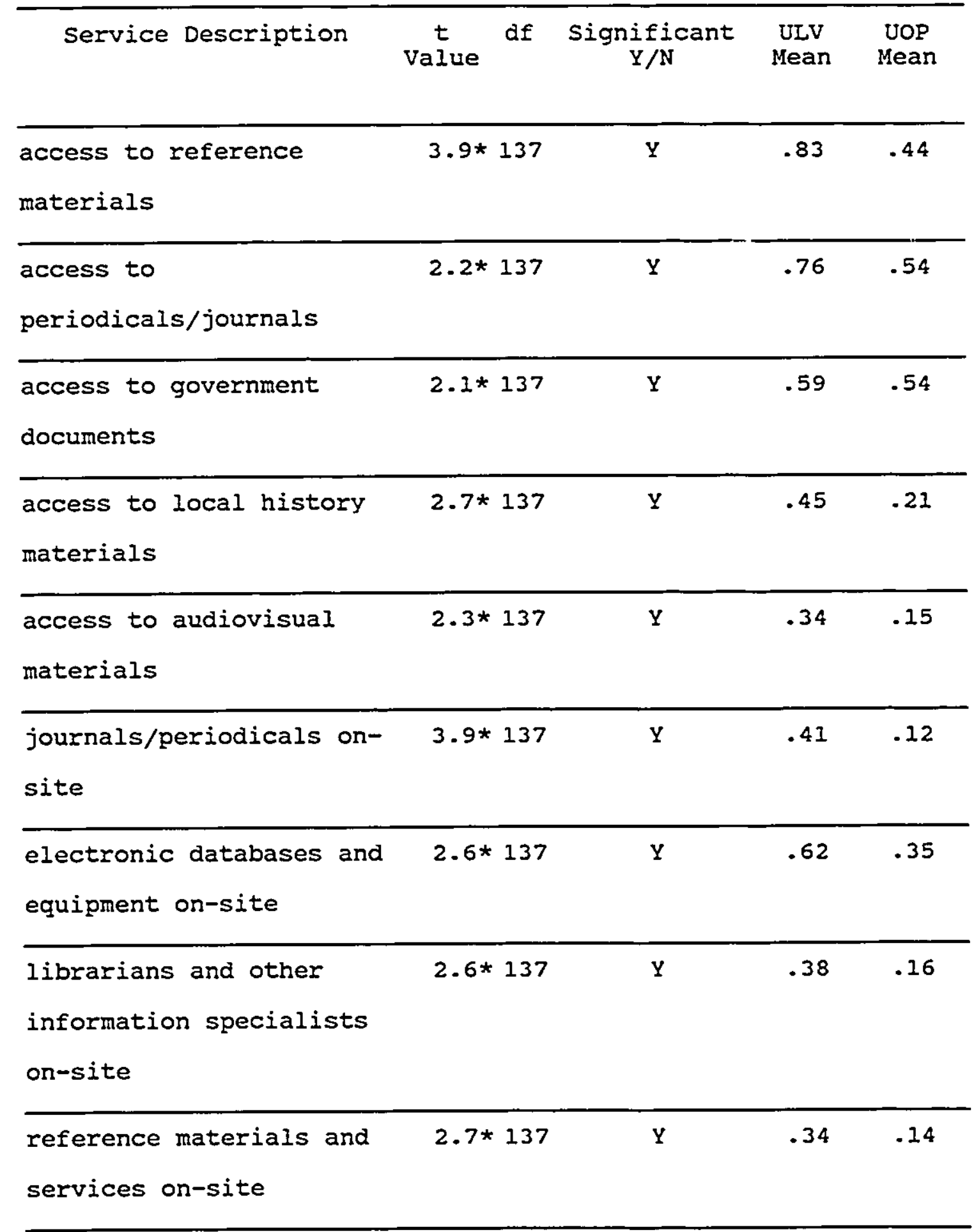


131

\begin{tabular}{|c|c|c|c|c|c|}
\hline Service Description & $\begin{array}{c}t \\
\text { value }\end{array}$ & $d f$ & 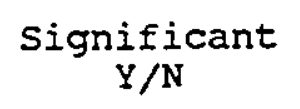 & $\begin{array}{l}\text { ULV } \\
\text { Mean }\end{array}$ & $\begin{array}{l}\text { UOP } \\
\text { Mean }\end{array}$ \\
\hline $\begin{array}{l}\text { interlibrary loan on-site } \\
\text { (the library will request } \\
\text { materials from other } \\
\text { libraries for you) }\end{array}$ & $3.6 *$ & 136 & $\mathrm{Y}$ & .39 & .12 \\
\hline $\begin{array}{l}\text { local history materials } \\
\text { on-site }\end{array}$ & $2.2 *$ & 136 & $Y$ & .14 & .04 \\
\hline $\begin{array}{l}\text { audiovisual materials on- } \\
\text { site }\end{array}$ & 1.2 & 136 & $\mathbf{N}$ & .14 & .07 \\
\hline $\begin{array}{l}\text { government documents on- } \\
\text { site }\end{array}$ & 1.1 & 136 & $\mathbf{N}$ & .07 & .03 \\
\hline other & .9 & 137 & $\mathrm{~N}$ & .00 & .03 \\
\hline
\end{tabular}

*p<.05, two-tailed 
Table F-2

Iibrary services the offered service Should Provide

\begin{tabular}{|c|c|c|c|c|c|}
\hline Service Descriptio:? & $\begin{array}{c}t \\
\text { value }\end{array}$ & df & $\begin{array}{c}\text { Significant } \\
Y / N\end{array}$ & $\begin{array}{l}\text { ULV } \\
\text { Mean }\end{array}$ & $\begin{array}{l}\text { UOP } \\
\text { Mean }\end{array}$ \\
\hline $\begin{array}{l}\text { does searches on } \\
\text { electronic databases for } \\
\text { students (for free) }\end{array}$ & .6 & 118 & $\mathbf{N}$ & .5 & .43 \\
\hline $\begin{array}{l}\text { does searches on } \\
\text { electronic databases for } \\
\text { students (for a fee) }\end{array}$ & 1.9 & 118 & $\mathrm{~N}$ & .35 & .17 \\
\hline $\begin{array}{l}\text { uses librarians and other } \\
\text { information specialists } \\
\text { to help students define } \\
\text { information requests }\end{array}$ & .5 & 118 & $\mathrm{~N}$ & .5 & .44 \\
\hline $\begin{array}{l}\text { uses librarians and other } \\
\text { information specialists } \\
\text { to explain how } \\
\text { information will best be } \\
\text { located }\end{array}$ & .3 & 118 & $\mathrm{~N}$ & .4 & .37 \\
\hline
\end{tabular}




\begin{tabular}{|c|c|c|c|c|c|}
\hline Service Description & $\begin{array}{c}t \\
\text { value }\end{array}$ & $d f$ & $\underset{Y / N}{\text { Significant }}$ & $\begin{array}{l}\text { ULV } \\
\text { Mean }\end{array}$ & $\begin{array}{l}\text { UOP } \\
\text { Mean }\end{array}$ \\
\hline $\begin{array}{l}\text { provide listing of } \\
\text { references and article } \\
\text { summaries of the search } \\
\text { results } \\
\text { (journals/periodicals } \\
\text { only) }\end{array}$ & .4 & 118 & $\mathbf{N}$ & .35 & .3 \\
\hline $\begin{array}{l}\text { provide a listing of } \\
\text { references of search } \\
\text { results (books and } \\
\text { materials, as well as } \\
\text { journal/periodicals) }\end{array}$ & .9 & 118 & $\mathbf{N}$ & .5 & .39 \\
\hline $\begin{array}{l}\text { provide fuli-text copies } \\
\text { of search results if } \\
\text { requested }\end{array}$ & .2 & 118 & $\mathbf{N}$ & .5 & .48 \\
\hline $\begin{array}{l}\text { provide actual material, } \\
\text { if requested }\end{array}$ & .3 & 118 & $\mathrm{~N}$ & .35 & .39 \\
\hline $\begin{array}{l}\text { access to interlibrary } \\
\text { loan (the library will } \\
\text { request materials from } \\
\text { other libraries for you) }\end{array}$ & .5 & 118 & $\mathrm{~N}$ & .5 & .44 \\
\hline
\end{tabular}


134

\begin{tabular}{|c|c|c|c|c|c|}
\hline Service Description & $\begin{array}{c}t \\
\text { value }\end{array}$ & $d f$ & $\underset{Y / N}{\underset{N}{\text { Significant }}}$ & $\begin{array}{l}\text { ULV } \\
\text { Mean }\end{array}$ & $\begin{array}{l}\text { UOP } \\
\text { Mean }\end{array}$ \\
\hline $\begin{array}{l}\text { access to reference } \\
\text { materials }\end{array}$ & .7 & 118 & $\mathbf{N}$ & .5 & .41 \\
\hline $\begin{array}{l}\text { access to } \\
\text { periodicals/journals }\end{array}$ & 1.2 & 118 & $\mathbf{N}$ & .55 & .4 \\
\hline $\begin{array}{l}\text { access to government } \\
\text { documents }\end{array}$ & 1.3 & 118 & $\mathrm{~N}$ & .6 & .44 \\
\hline $\begin{array}{l}\text { access to local history } \\
\text { materials }\end{array}$ & $2.3 *$ & 118 & $Y$ & .55 & .29 \\
\hline $\begin{array}{l}\text { access to audiovisual } \\
\text { materials }\end{array}$ & .4 & 118 & $N$ & .45 & .4 \\
\hline $\begin{array}{l}\text { journals/periodicals on- } \\
\text { site }\end{array}$ & 1.1 & 118 & $\mathbf{N}$ & .45 & .32 \\
\hline $\begin{array}{l}\text { electronic databases and } \\
\text { equipment on-site }\end{array}$ & .7 & 118 & $\mathbf{N}$ & .35 & .44 \\
\hline $\begin{array}{l}\text { librarians and other } \\
\text { information specialists } \\
\text { on-site }\end{array}$ & $2.0 *$ & 118 & $Y$ & .25 & .49 \\
\hline $\begin{array}{l}\text { reference materials and } \\
\text { services on-site }\end{array}$ & 1.2 & 118 & $N$ & .2 & .33 \\
\hline
\end{tabular}


135

\begin{tabular}{|c|c|c|c|c|c|}
\hline Service Description & $\begin{array}{c}t \\
\text { value }\end{array}$ & $d f$ & $\begin{array}{c}\text { Significant } \\
Y / N\end{array}$ & $\begin{array}{l}\text { ULV } \\
\text { Mean }\end{array}$ & $\begin{array}{l}\text { UOP } \\
\text { Mean }\end{array}$ \\
\hline $\begin{array}{l}\text { interlibrary loan on-site } \\
\text { (the library will request } \\
\text { materials from other } \\
\text { libraries for you) }\end{array}$ & $2.0 *$ & 118 & $Y$ & .15 & .38 \\
\hline $\begin{array}{l}\text { local history materials } \\
\text { on-site }\end{array}$ & 1.4 & 118 & $\mathrm{~N}$ & .1 & .24 \\
\hline $\begin{array}{l}\text { audiovisual materials on- } \\
\text { site }\end{array}$ & 1.2 & 118 & $\mathrm{~N}$ & .15 & .28 \\
\hline $\begin{array}{l}\text { government documents on- } \\
\text { site }\end{array}$ & .7 & 118 & $\mathrm{~N}$ & .2 & .27 \\
\hline other & .1 & 116 & $\mathrm{~N}$ & .05 & .05 \\
\hline
\end{tabular}

* $\mathrm{Q}<.05$, two-tailed 
Table F-3

Library services A Traditional university Library Provides

\begin{tabular}{|c|c|c|c|c|c|}
\hline Service Description & $\begin{array}{c}t \\
\text { value }\end{array}$ & $d f$ & $\begin{array}{c}\text { Significant } \\
Y / N\end{array}$ & $\begin{array}{l}\text { ULV } \\
\text { Mean }\end{array}$ & $\begin{array}{l}\text { UOP } \\
\text { Mean }\end{array}$ \\
\hline $\begin{array}{l}\text { does searches on } \\
\text { electronic databases for } \\
\text { students (for free) }\end{array}$ & .1 & 122 & $\mathbf{N}$ & .38 & .39 \\
\hline $\begin{array}{l}\text { does searches on } \\
\text { electronic databases for } \\
\text { students (for a fee) }\end{array}$ & .6 & 120 & $\mathbf{N}$ & .38 & .32 \\
\hline $\begin{array}{l}\text { uses librarians and other } \\
\text { information specialists } \\
\text { to help students define } \\
\text { information requests }\end{array}$ & .2 & 120 & $\mathbf{N}$ & .71 & .73 \\
\hline $\begin{array}{l}\text { uses librarians and other } \\
\text { information specialists } \\
\text { to explain how } \\
\text { information will best be } \\
\text { located }\end{array}$ & .4 & 120 & $\mathrm{~N}$ & .67 & .71 \\
\hline
\end{tabular}




\begin{tabular}{|c|c|c|c|c|c|}
\hline Service Description & $\begin{array}{c}t \\
\text { value }\end{array}$ & df & $\underset{Y / N}{\underset{N}{\text { Significant }}}$ & $\begin{array}{l}\text { ULV } \\
\text { Mean }\end{array}$ & $\begin{array}{l}\text { UOP } \\
\text { Mean }\end{array}$ \\
\hline $\begin{array}{l}\text { provide listing of } \\
\text { references and article } \\
\text { summaries of the search } \\
\text { results } \\
\text { (journals/periodicals } \\
\text { only) }\end{array}$ & 1.0 & 120 & $\mathbf{N}$ & .62 & .50 \\
\hline $\begin{array}{l}\text { provide a listing of } \\
\text { references of search } \\
\text { results (books and } \\
\text { materials, as well as } \\
\text { journal/periodicals) }\end{array}$ & 1.2 & 120 & $\mathrm{~N}$ & .07 & .50 \\
\hline $\begin{array}{l}\text { provide full-text copies } \\
\text { of search results if } \\
\text { requested }\end{array}$ & .8 & 120 & $\mathrm{~N}$ & .62 & .52 \\
\hline $\begin{array}{l}\text { provide actual material, } \\
\text { if requested }\end{array}$ & .1 & 120 & $\mathbf{N}$ & .62 & .62 \\
\hline $\begin{array}{l}\text { access to interlibrary } \\
\text { loan (the library will } \\
\text { request materials from } \\
\text { other libraries for you) }\end{array}$ & .2 & 120 & $\mathbf{N}$ & .71 & .75 \\
\hline
\end{tabular}




\begin{tabular}{|c|c|c|c|c|c|}
\hline Service Description & $\begin{array}{c}t \\
\text { value }\end{array}$ & $d f$ & $\begin{array}{c}\text { Significant } \\
Y / N\end{array}$ & $\begin{array}{l}\text { UIV } \\
\text { Mean }\end{array}$ & $\begin{array}{l}\text { UOP } \\
\text { Mean }\end{array}$ \\
\hline $\begin{array}{l}\text { access to reference } \\
\text { materials }\end{array}$ & .7 & 120 & $\mathrm{~N}$ & .86 & .79 \\
\hline $\begin{array}{l}\text { access to } \\
\text { periodicals/journals }\end{array}$ & .5 & 120 & $N$ & .86 & .81 \\
\hline $\begin{array}{l}\text { access to government } \\
\text { documents }\end{array}$ & .4 & 120 & $\mathrm{~N}$ & .81 & .77 \\
\hline $\begin{array}{l}\text { access to local history } \\
\text { materials }\end{array}$ & .6 & 120 & $\mathbf{N}$ & .67 & .73 \\
\hline $\begin{array}{l}\text { access to audiovisual } \\
\text { materials }\end{array}$ & .1 & 120 & $\mathrm{~N}$ & .76 & .75 \\
\hline $\begin{array}{l}\text { journals/periodicals on- } \\
\text { site }\end{array}$ & .4 & 120 & $\mathbf{N}$ & .86 & .82 \\
\hline $\begin{array}{l}\text { electronic databases and } \\
\text { equipment on-site }\end{array}$ & .6 & 120 & $\mathbf{N}$ & .81 & .64 \\
\hline $\begin{array}{l}\text { Iibrarians and other } \\
\text { information specialists } \\
\text { on-site }\end{array}$ & .3 & 120 & $\mathbf{N}$ & .86 & .83 \\
\hline $\begin{array}{l}\text { reference materials and } \\
\text { services on-site }\end{array}$ & .2 & 120 & $\mathrm{~N}$ & .86 & .84 \\
\hline
\end{tabular}


139

\begin{tabular}{|c|c|c|c|c|c|}
\hline Service Description & $\begin{array}{c}t \\
\text { value }\end{array}$ & df & $\begin{array}{c}\text { Significant } \\
Y / N\end{array}$ & $\begin{array}{l}\text { ULV } \\
\text { Mean }\end{array}$ & $\begin{array}{l}\text { UOP } \\
\text { Mean }\end{array}$ \\
\hline $\begin{array}{l}\text { interlibrary loan on-site } \\
\text { (the library will request } \\
\text { materials from other } \\
\text { libraries for you) }\end{array}$ & 1.0 & 120 & $\mathrm{~N}$ & .90 & .81 \\
\hline $\begin{array}{l}\text { local history materials } \\
\text { on-site }\end{array}$ & 1.1 & 120 & $\mathrm{~N}$ & .67 & .78 \\
\hline $\begin{array}{l}\text { audiovisual materials on- } \\
\text { site }\end{array}$ & 1.4 & 120 & $\mathbf{N}$ & .67 & .80 \\
\hline $\begin{array}{l}\text { government documents on- } \\
\text { site }\end{array}$ & .9 & 120 & $\mathbf{N}$ & .62 & .71 \\
\hline other & 1.3 & 122 & $\mathrm{~N}$ & .1 & .25 \\
\hline
\end{tabular}

ॠp<.05, two-tailed 
Appendix G

\section{Survey Respondents' Comments}

How would you describe [offered library services]?

(number 3 faculty survey and number 6 student survey:

\section{ULV Eaculty}

No knowledge. (3)

Don't know much about it.

Have not utilized.

ULV Students

Have not used. (2)

on-line full text periodicals and newspaper articles.

UOP Faculty

Don't know. (4)

Unknown. (2)

Unsure.

May try in future.

Materials upon request.

yop students

Don't use. (14)

Unknown (3)

Request over phone \& they fax or mail.

Limited periodical database.

Electronic library/fax

Electronic access of various databases. 
What is final form (i.e. Iisting article, book) you usually get from [offered library services]? (number 6 faculty survey and number 9 student survey)

ULV Faculty

\section{ULV students}

Information over the phone.

UOP Faculty

Not used. (2)

UOP Students

Copy of article.

Article

Index and abstract, then I go to unive. ity library to find article.

[Offered Iibrary service] is an electronic based service supported by traditional library services. If you were to compare electronic library services with traditional library services, please mark the comment(s) that most closely reflect how you feel. (number 14 faculty survey and number 17 student survey)

\section{ULV Faculty}

ULV students

Don't know about service.

\section{UOP Faculty}

Cannot compare.

I am not sure. 
I don't know enough about LRS/AIS to use.

Have had no occasion to use.

Have not fully utilized service.

I would rather use electronic but don't know how.

Don't really use libraries to prepare lectures.

Augment test with materials from current or recent issues of Wall Street Journal and other periodicals.

I want all of the information of all library knowledge on my home PC.

Most electronic services are cumbersome to use and user un-friendly. User interfaces must be improved if people are expected to use them.

UOP Students

Do not use. (4)

No basis for comparison.

I need more information on electronic services.

Took too long to get.

Electronic services are easy because I can access from home.

Computer access to information is great.

Faster access.

I can accomplish search much quicker on my own (rather than using the service).

The item will never be signed out with electronic library. 
I use both equaliy.

Diamond Bar not on electronic service.

A library is accessible and you can get information

Do you have additional comments about electronic and

traditional library services? (number 19 faculty survey and

number 22 student survey)

Usage/Knowledge of Service

ULV Faculty

I use a service at my hospital which has computerized search and interlibrary loan services with the UCIA campus. I am supportive of ULV's service, but don't use it. It is easier for me to use the librarians on staff at the hospital library.

I am a part time faculty and have had no contact with the electronic Iibrary.

Not really sure what electronic service provide. Would like to know more about it and how to use it. Poor advertisement about library services. Not enough publicity about library services, students are confused.

An awareness program for adjunct faculty would be nice. Really not applicable for me or ny classes since we are able to get all reading materials through my own efforts. In Ventura county, there are no big research libraries. Students must utilize electronic service or travel to Santa Barbara or the valley. 
UIV students

I haven't been informed about the off-campus services

but would like to know more. (2)

Never used.(2)

This is my second course and I haven't had to use the library. The process seems unclear.

Have not had a class that required s.se if electronic library.

UOP Faculty

I just started teaching a* UOP, newly aware of service. (4)

I am aware some sort of services is available to the students, but I know nothing about it. in orientation for faculty would be helpful.

We need some training on the service.

Make electronic library use mandatory for incoming students for each ccurse.

Electronic services should be publicized among faculty more extensively.

I have my own system set up for my students to use. Uop students

I have never used IRS/AIS at UCP. However, I feel that this service will be useful. (5)

I have never used AIS at UOP but have heard good things about it. 
I used the LRS once, and found it to be very helpful. Don't know much about it.

Favorable comments About offered Service:

ULV Faculty

ULV students

Excellent service.

The service from the main campus library has been

outstanding.

very useful and valuable.

Convenience \& availability count most in this

consideration.

This is valuable time-saving measure. Allows me to

focus on my assignment.

When working and doing reports having information fax is helpful.

When I can hook up at home by computer the info that would come from a research library, I will be happy.

The more that can be done at home the better.

UOP Faculty

Very pleased its available.

If students are trying to complete a degree program and they cannot get access to a library -- LRS is great it gives you a starting point. Developing good library habits is an important factor for students and faculty. 
I have used service to a limited extent in the past. I found that when I knew what and where to look I found the material easily. The problem is knowing where to look and what to look for.

The UOP AIS is an excellent source to enhance a local library search. Due to budget cut and student time demands it provides an excelient service. I suggest students do both an AIS and on-site Iibrary search for their research projects.

UOP students

Satisfied.

UOP service is courteous and efficient, although inadequate for full research.

I've been told it's excellent. Unfavcrable comments about offerea Service

UIV Faculty

ULV students

off-campus library services never respond.

The waiting period for off campus library service is too long.

Not very good if a time factor is involved. The attitude on the customer service rep appears to me that she doesn't have the time to help me. UOP Faculty 
My students do not use electronic library service as it is too difficult to use.

The marketing of electronic service is either poor or doesn't exist.

Inconvenience of existing services time for response.

I found the information provided to be very difficult to understand and confusing. IRS/AIS was not covered in six week certificate programs.

This could be an important and vital adjunct to the UOP system. Unfortunately it is woefully short. We need a decent library on-site or an agreement with UC or CSU system.

I don't encourage students to use them in a five week research class because they say it takes too long to get the information and then the information is not what they need. It could be they are not specific enough in the information.

The IRS is very poorly marketed and it is my understanding, slow to respond.

My experience has shown that AIS provides limited resources for research purposes. If they could provide more comprehensive articles, dissertation abstracts, psych. lit. all services by Cal. State or UC system then there would be no need to go to other libraries.

The UOP modual is quite complete for the instructors. It is not often necessary to search for additional material. 
Also the non-traditional structure of UOP sometimes makes it seem the electronic service is non-accessible or inconvenient.

Not very effective according to students.

Inadequate to marginal.

uOP Students

A training program would be useful. (2)

I wish it didn't cost so much to order a copy of magazine or any kind of article.

It would be better if AIS could provide a copy of the entire article.

LRS should be free of charge

The electronic library should be more accessible for UOP students.

On-site computers to access library materials are needed.

If universities would offer more in the electronic services, it would help.

Too siow.

I've found it easier to use Compuserve and the library over AIS, they're hard to reach. Would like to utilize the service, but is both instances the service has provided material I couldn't use. speed in researching and mailing would be helpful, shorten turnaround time. 
The weakness of current AIS services at UOP is that they are not exclusively for students.

Electronic is faster but if you need info. for a 5 week class they should send it faster.

LRS takes 10 days to present complete runs in a 5 week course. That amount of time is not acceptable.

Too confusing takes too long to get material.

Favorable Comments About Electronic Services in General

ULV Faculty

ULV students

The information market is booming and will continue to boom in the years ahead.

I would find electronic searches for newspaper or periodicals with the capability to get full text very helpful.

Electronic services are used more often when a time factor is not involved.

Electronic services are convenient and very accessible. I am glad the Iibrary offers them.

I believe on-line library services to be of value.

I use an electronic library at work and find it very useful.

FAX back service coupled with proper indexes could be extremely powerful. 


\section{UOP Facuity}

With the increased availability of technology and communications, the traditional library as we know it will cease to exist.

I believe we are transitioning to the electronic Iibrary.

\section{UOP students}

Like the ability to zero in on subjects researching and have immediate information.

I think the electronic library is great.

Electronic services provide greater flexibility to access information.

Electronics is the future and is much faster. But having a human to ask for assistance is nice.

Electronic Iibraries would be a much better service if fee for retrieved was less.

Very helpful if the library has a good system.

Unfavorable comments About Electronic Services in General

ULV Faculty

\section{UIV Students}

Anytime one becomes dependent on electronic services, often times they use bend information to meet the need.

\section{UOP Faculty}

The cost of electronic in terms of modem/fax out weigh benefits for me. 
Wish it were cheaper and they all had 14.4 modems. UOP Students

Communicating electronically for data searches can be difficult.

It is sometimes difficult to pecifically define the scope of the information needed.

Favorable Comments Traditional Library Service

ULV Faculty

I use the community college Iibrary, feel uncomfortable using electronic mediums.

\section{ULV students}

Preference is a matter of personal comfort. I realize the value of electronic service but am more comfortable with traditional services.

I'm a CAPA student so I use the main Iibrary exclusively.

\section{UOP Faculty}

I prefer traditional library service, but local funding reductions have resulted in over-crowding, limited hours and harried staff. This is an opportunity for the electronic library to expand its influence.

uop students

Just nice to read through the actual text.

Some traditional libraries do provide the databases to do searches. 
Found best source of all at Yorba Linda Library on Infotrack.

Comments on Both Services Combined

ULV Faculty

The combination is a great addition to modern research, study and learning.

Encourage more and more library research for term papers.

uLV Students

UOP Faculty

I see electronic library services as a supplement to a traditional library that offer convenient "quick and dirty" searches.

Electronic and traditional combined are very valuable, but electronic should be more user friendly, less intimidating and more accessible. Traditional libraries and electronic should be combined into one resource.

A combination of the two is very synergistic. The future is full electronic data interchange (EDI) and the electronic Iibrary is going to be part of it.

I can see electronic services being much more responsive to users needs. However, I cannot see electronic service completely replacing traditional services. uOP students 
I would use both although I use traditional Iibraries more often.

Would like the advantage of traditional liorary and reasonable electronic service. Comments About the Survey

ULV Faculty

ULV Students

you ask the questions to slant the results in the manner you want.

Uop Faculty

Good luck, very interesting questionnaire.

A few questions left no room for the novice to answer. Questionnaire doesn't apply to me.

Instrument too complex.

UOP Students

Survey too long. (5)

Good idea, good luck.

Number 18 is too complicated/confusing. 